\title{
As leis da estética na arte russa*
}

Ludmila Menezes Zwick"

Resumo: Em concordância com o uso das leis da estética, propostas por Vilayanur S. Ramachandran, ora referidas a algumas pinturas russas, este texto dialoga com um possível método de leitura da pintura que seja capaz de compreender parte do processo de elaboração de uma obra de arte. Ou seja, o ordenamento de seus elementos, suas formas, suas cores e o seu movimento, enfim, os recursos artísticos de caráter universal que, por serem a aplicação do conhecimento de princípios que almejam determinados resultados, instrumentalizam o artista para que ele consiga consubstanciar o imaginativo de suas ideias na efetiva criação de uma imagem expressa.

\begin{abstract}
In accordance with the use of the laws of aesthetics, proposed by Vilayanur $\mathrm{S}$. Ramachandran, here referred to some Russian paintings, this text dialogues with a possible method of reading painting that is able to understand part of the elaboration process of a work of art. That is to say, the ordering of its elements, its forms, its colors, and its movement, in short, the artistic resources of universal character which, because they are the application of knowledge of principles that aim at certain results, instrumentalize the artist so that he can consubstantiate the imaginative of his ideas in the effective creation of an express image.
\end{abstract}

Palavras-chave: Leis da estética; Arte russa; Vilayanur S. Ramachandran. Keywords: Laws of Aesthetics; Russian Art; Vilayanur S. Ramachandran. 
* Artigo submetido em 05 de setembro de 2018 e aprovado em 12 de novembro de 2018.

** Mestra em Estética e História da Arte pela Universidade de São Paulo e doutora em Literatura e Cultura Russa pela mesma universidade. E-mail: lincecapelia@ gmail.com.

\section{Introdução}

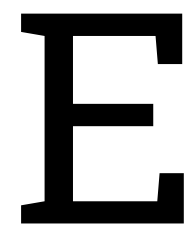

ste texto apresenta uma leitura de algumas pinturas russas pautada pelo referencial teórico da neuroestética, que utiliza como ferramenta de leitura as leis da estétical estabelecidas por V. S. Ramachandran. Com isso, sai do primeiro plano a reunião de dados iconográficos ou de datação estilístico-cultural como um fator-chave, bem como a vinculação mais acentuada aos estilos e aos movimentos artísticos. A elaboração da mensagem poética ${ }^{2}$ pela via pictórica encontra-se inserida em um contexto humano repleto de leis - o que associa a arte à ciência - que tentam orientar o homem em meio a tantas aleatoriedades. Então, para expressar-se, o artista se vale de princípios que se encontram presentes no que a neuroestética denominou de universais artísticos. ${ }^{3} \mathrm{O}$ empenho do

\footnotetext{
${ }^{1}$ A fim de descobrir princípios universais na arte baseados no conhecimento da neurociência visual em particular, V.S. Ramachandran propôs dez princípios, dos quais oito já haviam sido mencionados em seu artigo escrito em parceria com William Hirstein, intitulado "The Science of Art", de 1999. Num trabalho anterior, considerei nove dessas leis - listadas por Ramachandran na obra o que o cérebro tem para contar - e abdiquei da lei ou princípio do equilíbrio, por sua proximidade com o princípio do ordenamento e até mesmo com o da proporcionalidade ou simetria; a lei do equilíbrio não foi devidamente discutida por Ramachandran, mas, a partir das imagens, podemos fazer inferências.
}

20 que se relaciona, de certo modo, com o que Semir Zeki contemplou em seu ensaio Esplendores e misérias do cérebro, ao tratar da capacidade que qualquer sistema tem de armazenar informação de forma eficiente para capacitá-lo a abstrair e formular ideias, o que é propiciado pelo conflito entre a experiência do particular ou concreto e aquilo que o cérebro desenvolveu a partir da experiência, mediado pela variabilidade da seleção evolutiva, fonte de nossos êxitos, mas também de nossas misérias (ZEKI, 1999).

${ }^{3}$ Os estudos de Vilayanur S. Ramachandran (2003) revelam o que ele denominou de base neurológica dos universais artísticos. Para o autor, embora existam centenas de tipos de arte - arte grega clássica, tibetana, Khmer, bronzes Chola, arte renascentista, impressionismo, expressionismo, cubismo, fauvismo, arte abstrata e mais uma lista interminável -, há em toda essa diversidade de estilos alguns princípios gerais, ou "universais artísticos", que atravessam as fronteiras culturais. Seria assim possível chegarmos a uma "ciência da arte". Da variação que vemos na arte, ele supõe que $90 \%$ deriva da diversidade cultural, e apenas $10 \%$ relacione-se às leis universais comuns a todos os cérebros. Os $90 \%$ culturalmente impulsionados são estudados pela história da arte. Como cientista, ele se mostra interessado nos $10 \%$ que seriam os universais artísticos, cuja pesquisa é realizada a partir de testes de 
artista em criar a partir da realidade faz-se em uma imagem que expressa um universo fechado, insubstituível, que o faz vencer a transitoriedade das coisas. As leis da estética instruem o leitor quanto às suas limitações e, ao mesmo tempo, quanto às suas ferramentas de leitura; tais princípios são uma busca por compreensão do caminho expressivo.

A tela pintada - objeto artístico concreto - é uma expressão interligada ao self ${ }^{4}$ do artista. A concretização de uma pintura demanda a transcendência de uma ideia, uma vez que a ideia de uma obra não a efetiva. Para seu ato criador, o artista vale-se de uma série de conhecimentos prévios que são intuitivos, mas também dedutivos. Aproximada de questões relacionadas à percepção do mundo e dela mesma, como faz um cientista ao questionar o objeto de seus estudos, a arte, concretizada em pintura, revela sua humanidade e sua poesia em um emaranhado intenso e imenso de percepções expressas; além da emoção, a arte precisa se valer de meios para comprovar pela razão e pela experiência sua substância.

Ao concretizar uma ideia em expressão pictórica, o artista alia-se à beleza do mundo frente à força da morte e do esquecimento. Sua obra, com a presença ou não de uma personagem, torna-se a integridade de uma mensagem vibrante da unidade humana. A arte recoloca o homem na ordem da natureza e não apenas na história; sacia a fome de liberdade e dignidade que o habita. Em meio às possibilidades expressivas, nas quais a linguagem de cada artista se encarrega de ordenar e reordenar, além da escolha do local a ser narrado, um cenário campesino ou citadino, por exemplo, temos leis que atuam no intuito de sustentar o caráter estético e, por que não, poético da obra; da sobriedade ou exagero dos contrastes ao deslocamento das personagens, ao ritmo lento e melancólico ou acelerado e vivaz. Sabemos que o uso das leis não exime o artista de suas dúvidas, angústias, alegrias, tristezas e nem o delimi-

conjecturas por ser um estudo empírico do cérebro; tal estudo nomeou essa nova disciplina, a neuroestética, nome dado pelo estudioso Semir Zeki.

4 Para Ramachandran, um dos maiores mistérios a serem enfrentados é o da natureza do self, que foi extensivamente estudada por vários tipos de estudiosos, mas que ainda não está bem definida. 
ta em sua capacidade criativa, mas esse uso reconhece que, para unir o singular ao universal, o artista apresenta ao leitor uma imagem legível, sem que este seja hábil na aplicação de sua técnica. As denominadas leis da estética são as seguintes: 1) efeito de deslocamento de pico; 2) agrupamento e ligação perceptivos; 3) contraste; 4) isolamento; 5) esconde-esconde, ou solução perceptual de problemas; 6) simetria; 7) aversão a coincidências; 8) repetição, ritmo e disposição metódica, ou ordenamento; 9) equilíbrio e 10) metáfora.

\section{A lei do efeito de deslocamento de pico}

A maneira como nosso cérebro responde a estímulos exagerados é considerada pela lei do efeito de deslocamento de pico, o qual ocorre quando o artista entra num espaço que Ramachandran denomina "espaço abstrato de postura" para transmitir uma postura requintada. Para ele, os artistas de porte descobriram isso ao explorar os figurais primitivos e nossa gramática perceptual, criando estímulos ultranormais, capazes de excitar de modo mais intenso certos neurônios visuais em contraposição a imagens de aparência realista. Essa é a essência da arte abstrata e também um recurso utilizado pelos impressionistas, "o efeito de deslocamento de pico no espaço abstrato de cor, não no 'espaço de forma"'. ${ }^{5}$ Tais estímulos ultranormais também explicariam a atração por certas características que vemos nas pessoas.

Em arte, não podemos considerar que esse deslocamento - o apontamento da essência da obra -, seja realizado apenas por uma motivação encantadora, pois ele pode conduzir o leitor ao estarrecimento pela via de uma motivação mais visceral e agressiva. Esse deslocar de nossa atenção de modo tão ponderativo, que nos conduz ao encantamento ou à inquietude, pode nos incomodar rumo à raiva ou nos atrair rumo à paz.

Um caso de utilização dessa lei, para Ramachandran, encontra-se em obras como as do artista François Boucher (17031770), cujas pinturas se valeram do fato de o cérebro dos pri-

${ }^{5}$ RAMACHANDRAN, 2014, p. 264-269. 

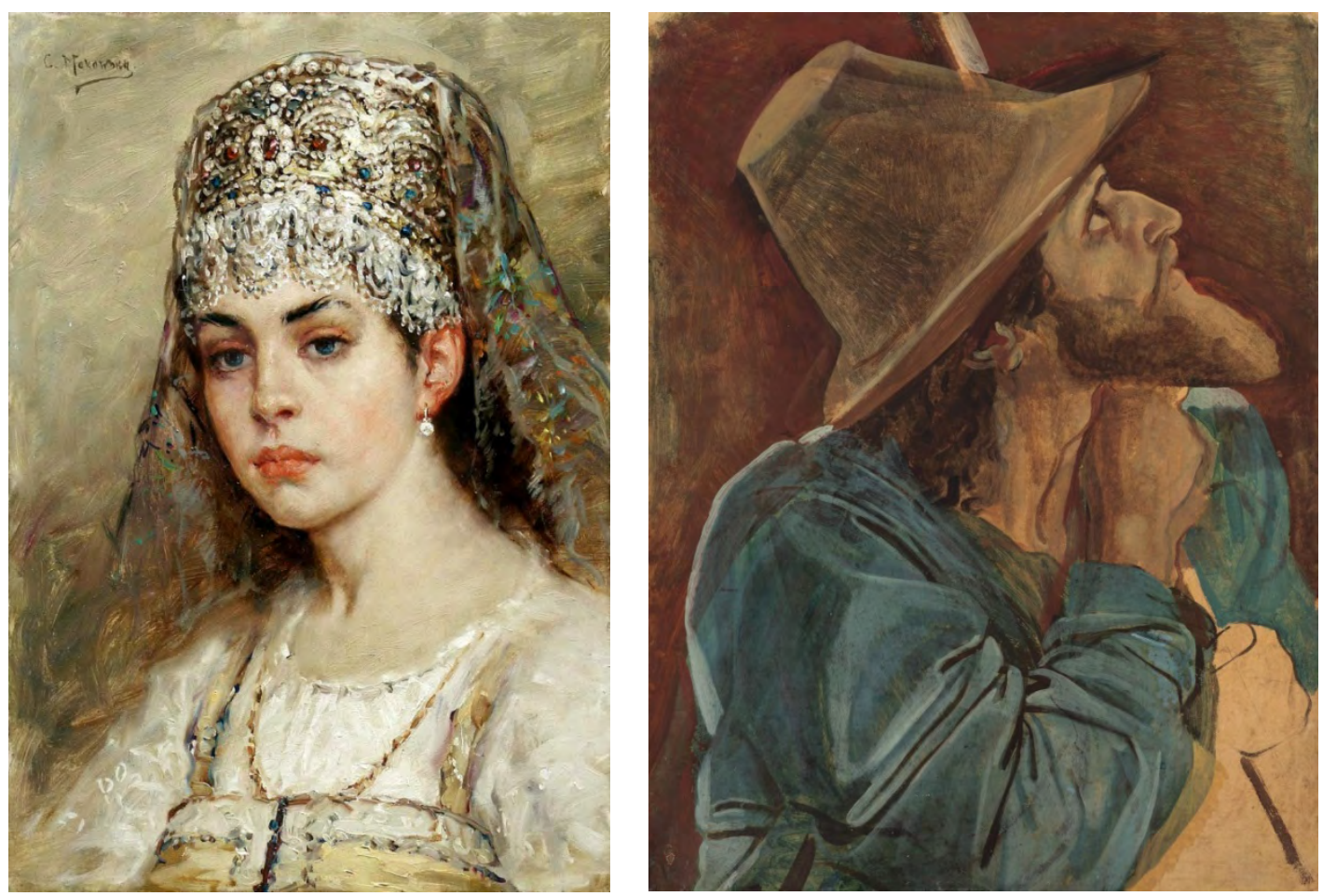

Fig. 1. Boiárina, Konstantín Makóvski, 1880, óleo sobre tela, $42 \times 29 \mathrm{~cm}$, coleção privada.

Fig. 2. Um viajante, segunda metade de 1830 , óleo sobre tela, 57,2x43,7cm. Galeria Tretiakóv, Moscou.

matas possuir módulos especializados relacionados a outras modalidades visuais - profundidade de cor e movimento -; o artista então explora o efeito de deslocamento de pico nas dimensões além do espaço da forma, como o espaço da cor ou o espaço do movimento. No caso dos nus rechonchudos de Boucher e nas fisionomias de querubim, ocorre um exagero nas características femininas para demarcar em cores a distância entre macho e fêmea - e de bebê - por meio de um realce dos tons rosados de pele visando à ideia de um absurdo e irreal aspecto salutífero. No caso de Boucher e de alguns artistas como Konstantín Makóvski (1839-1915), o exagero de alguns atributos - neste artista, a beleza russa feminil de tez saudável e lábios sensuais (fig. 1) - podem ser identificados de modo relativamente fácil; outro artista que se expressou nessa 
Fig. 3. Inverno, Konstantín Koróvin, 1894, óleo sobre tela, $37,2 \times 52,5 \mathrm{~cm}$. Galeria Tretiakóv, Moscou. mesma toada foi Vítali Tíkhov (1876-1939), em obras como Vênus diante do espelho (1920). O princípio aparece também no estender do queixo a acompanhar o chapéu com o intuito de dar ênfase ao que está entre eles, o olhar do viajante (fig. 2), de Aleksandr Ivánov (1806-1858); contudo, nem sempre o artista deixa tão evidente seu proposital exagero.

A motivação desse deslocamento, no caso de boa parte das obras de Pável Filónov (1883-1941), segue pela via que se expressa no espaço da forma - quando a forma delimita a cor (fig. 4) -, e, no caso de Konstantín Koróvin (1861-1939), esse deslocamento de pico se dá no espaço da cor - quando a cor delimita a forma (fig. 3). Tanto Filónov quanto Koróvin, em estilos distintos, também se valem do recurso da lei do agrupamento, ou do contraste, já que o uso de um princípio não exclui o de outros, mas ambos dão primazia a um personalista modus faciendi.

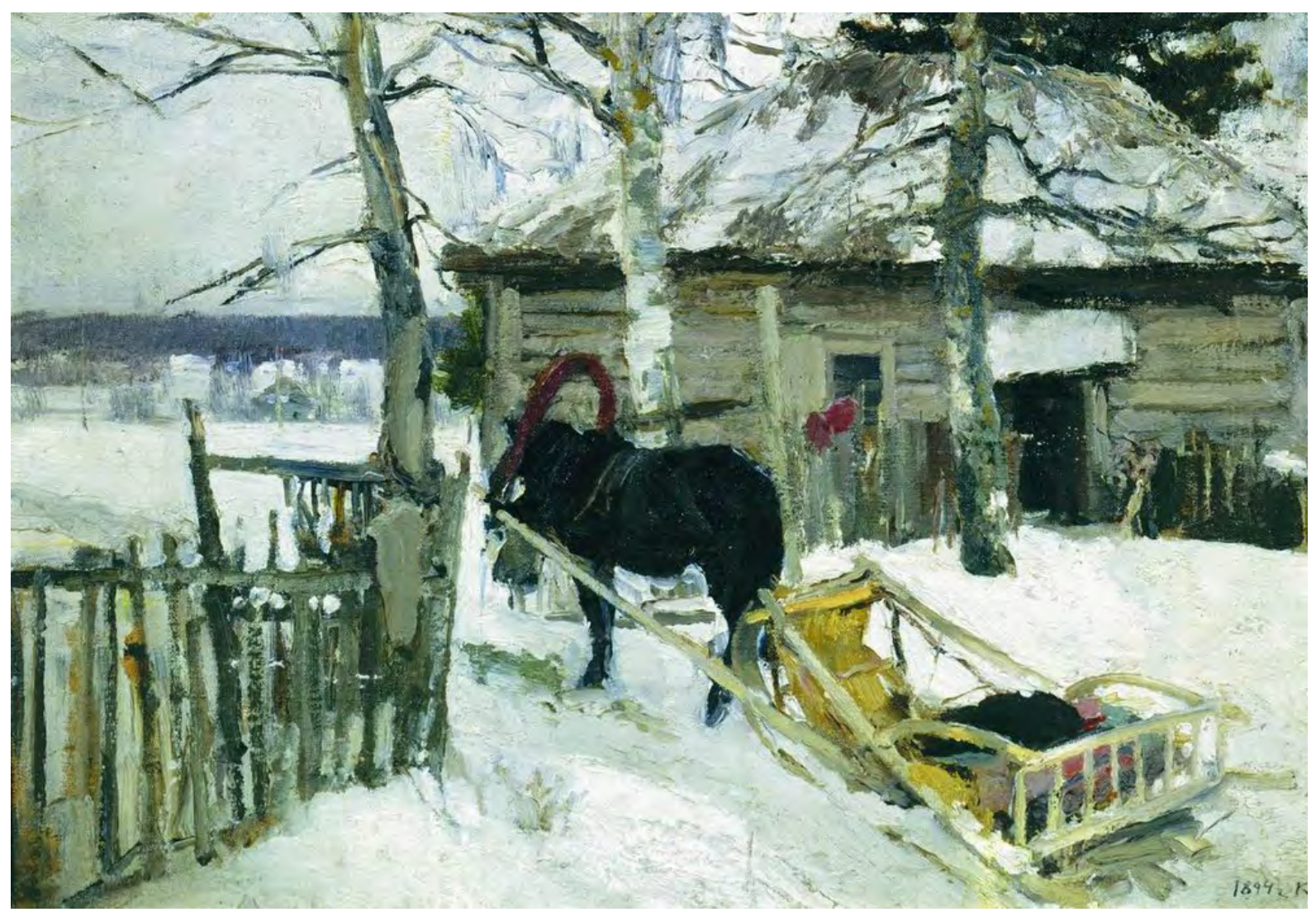


As leis da estética na arte russa

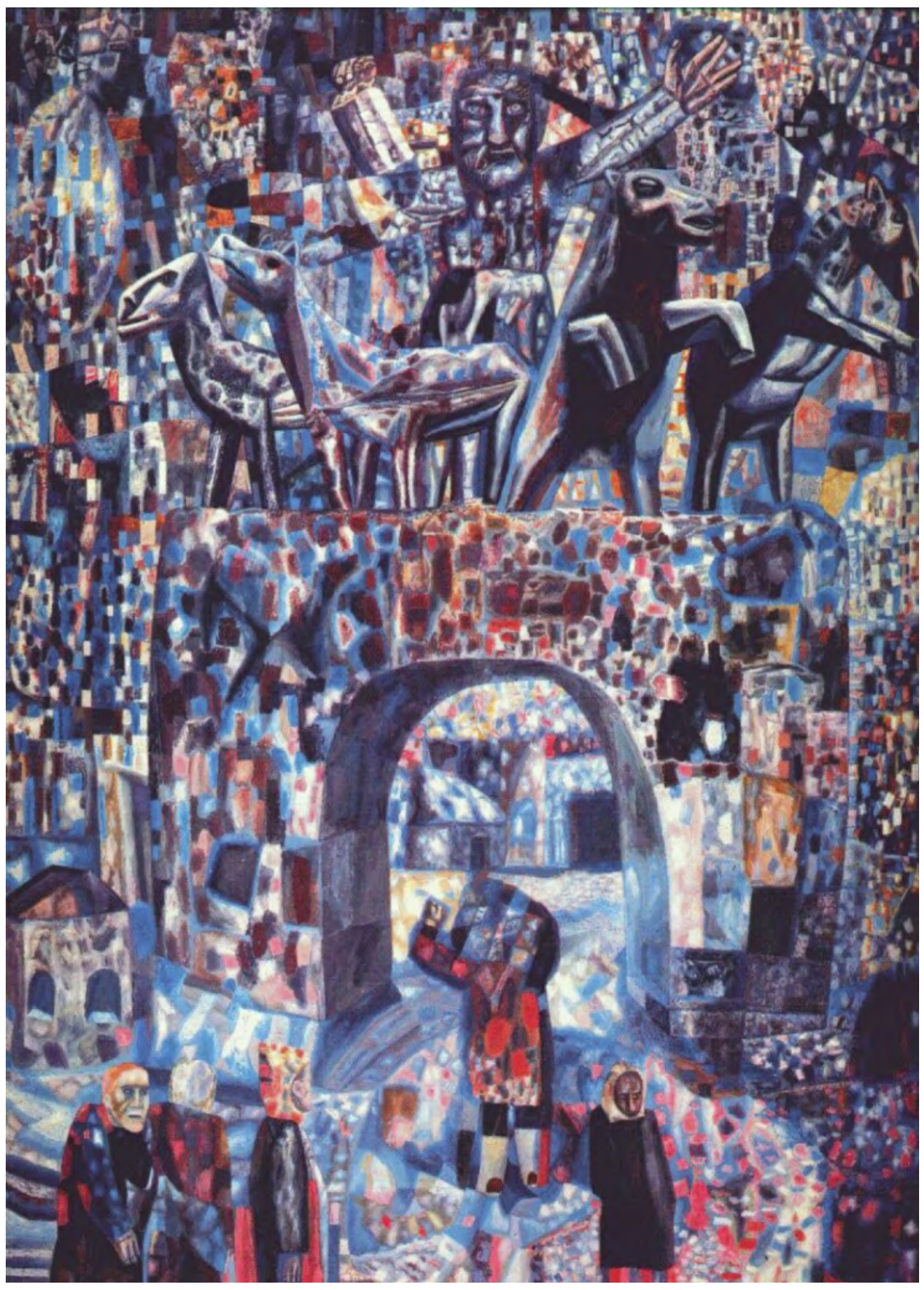

Fig. 4. 0 arco do triunfo de Narva, Pável Filónov, 1929, 88x62cm. Museu Estatal Russo, São Petersburgo. 


\section{A lei do agrupamento}

A lei do agrupamento foi descoberta na virada do século XX por psicólogos da Gestalt. Tal agrupamento foi e é utilizado tanto por artistas do Renascimento quanto por estilistas de moda, podendo ser definido como a repetição de uma mesma cor como parte de vários objetos não relacionados. $\mathrm{O}$ artista recorre a um número limitado de cores, e o nosso cérebro delicia-se com o intuito de derrotar a camuflagem e detectar objetos em cenas completamente cheias, bem como em agrupar as manchas de cores semelhantes. "Outro princípio de agrupamento perceptual, conhecido como da boa continuidade, declara que elementos gráficos que sugerirem um contorno visual contínuo tenderão a ser agrupados juntos". ${ }^{6}$

Em um mundo ruidoso, as partes mais iniciais do nosso sistema visual são projetadas, em grande parte, para detectar sinais; as correlações no campo visual, quando descobertas, dão um fôlego a esse empenho do olhar, tornam gratificante a natureza de encontrar uma figura entre um fundo barulhento. Os agrupamentos podem ocorrer em distintas dimensões perceptivas - espaço, cor, profundidade e movimento -, embora sejam reforçados de modo individual. A produção de uma experiência esteticamente agradável ligar-se-ia assim à presença de agrupamentos em várias dimensões perceptivas na arte. Para tal, o artista recorre a um número limitado de cores, desafiando o leitor a detectar objetos em cenas completamente cheias (fig. 5 e 6); é preciso agrupar as manchas de cores semelhantes para conseguir detectar cada elemento em cena. Tal princípio de agrupar teria que seguir, em muitas ocasiões, por uma via oposta à da lei do contraste, sem abandoná-la. 0 artista utiliza-se de uma artimanha expressiva que concorda com as artimanhas do nosso cérebro.

Agrupar de um modo que faça sentido, para que o leitor, ao deparar-se com as várias camadas, consiga construir às suas vistas a substância da obra, implica compreender como se dá o processo de derrota da camuflagem, assim como esclarecer

${ }^{6}$ Ibidem, p. 256-261. 
pictorialmente essa camuflagem para que ela seja vencida pela visão do leitor. Associar a visão e a cor ao som e ao sentido do leitor, a sensação, ao estar diante de uma obra tão ordenada ou caotizada pode assemelhar-se à narrativa elaborada por um poema que, ao contrastar cenários frios ou quentes, é capaz de conduzir-nos a essas emoções pelo viés dos liames descritivos expressos com base em nossa memória ou em nossa imaginação. $\mathrm{O}$ tom da cor imprime ritmo à narrativa pictórica. Em boa parte de sua obra, Filónov agrupa contrastando, assim como faz Aristarj Lentúlov (1882-1943) em obras como Igrejas. Nova Jerusalém (1917).

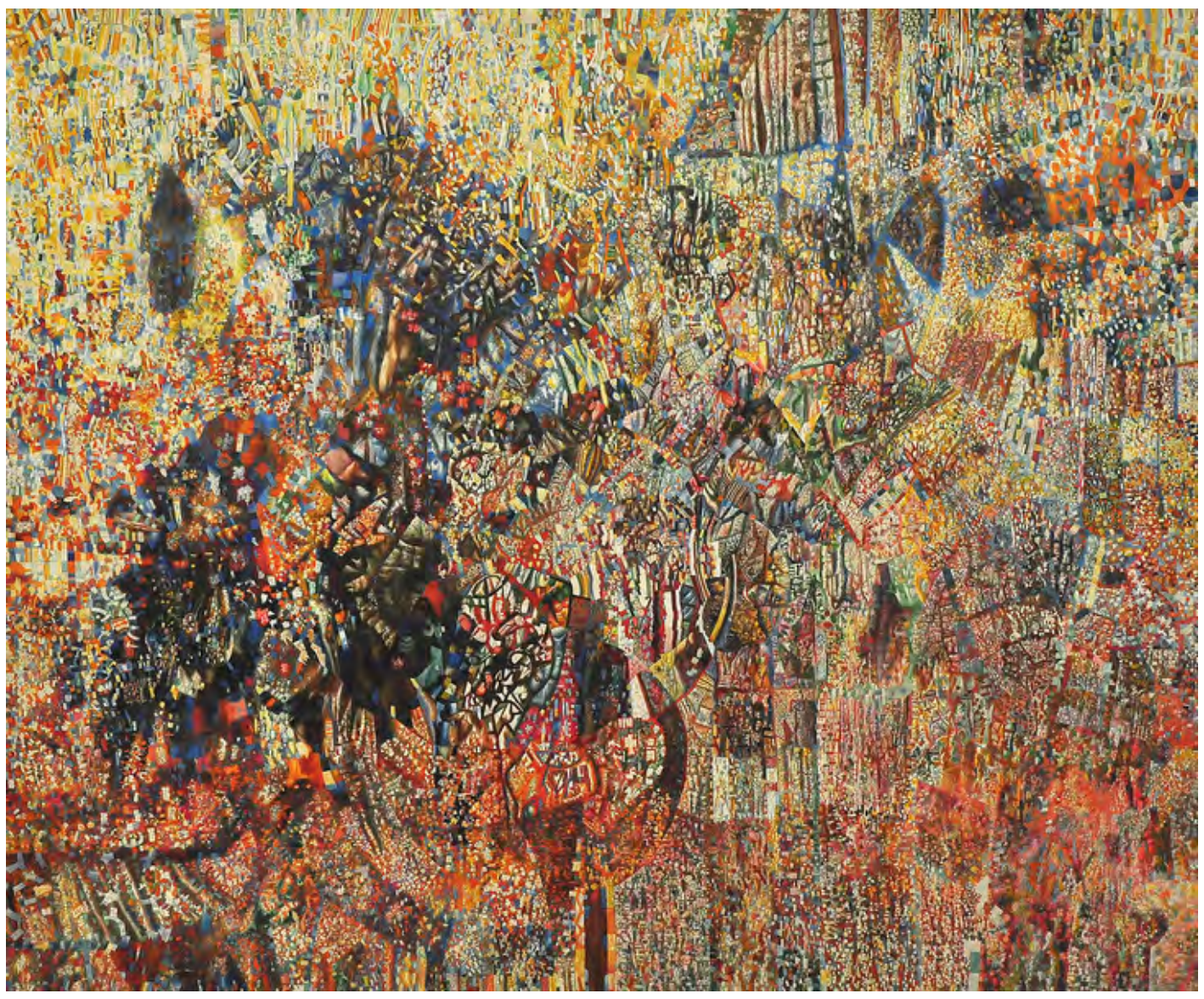

Fig. 5. Fórmula da primavera, Pável Filónov, 1928-1929, óleo sobre tela, 250x285cm. Museu Estatal Russo, São Petersburgo. 


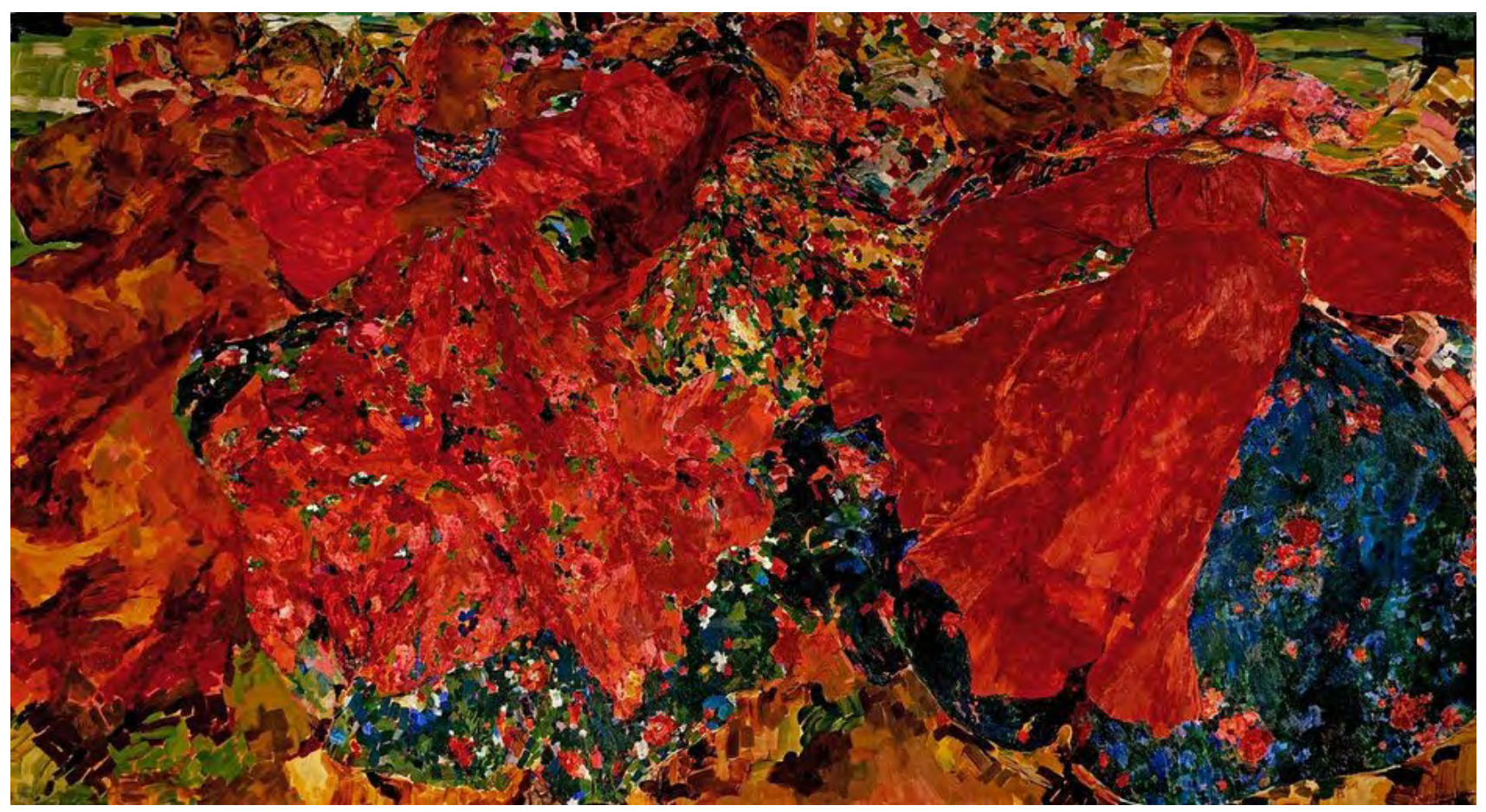

Fig. 6. 0 redemoinho, Filípp Maliávin, 1906, óleo sobre tela, $223 \times 410 \mathrm{~cm}$. Galeria Tretiakóv, Moscou.
O agrupamento ou o contraste relacionam-se à sensação de sobriedade ou de euforia, ao tom emotivo da obra, à sensação de uma temperatura mais amena, mais fria ou mais acolhedora, mais quente; agrupar e contrastar foram recursos muito frequentes na arte do século XX. O agrupamento associa-se à mudança de perspectiva utilizada pelo cubismo, por exemplo, quando o ponto de fuga é propositalmente suprimido a fim de reunir vários planos num único; mas nem sempre esse procedimento é o mais representativo do agrupamento; em muitas de suas obras, Filónov agrupa mantendo a perspectiva. Ele quer nos mostrar tudo de um espaço ao mesmo tempo, sem que para isso tenha de extrair certas perspectivas que direcionam o olhar do leitor para vários locais da obra, diferentemente do cubismo, que amalgama o todo para ser visto num só golpe de vista para, em seguida, ser depurado; a arte analítica quer a depuração do olhar em vários golpes de vista. 


\section{A lei do contraste}

O contraste é o código da pintura. Para que esse princípio do contraste se efetive, ele deve ocorrer entre duas regiões homogêneas espacialmente contíguas da obra, uma mudança relativamente súbita em luminosidade, cor, textura ou profundidade. Em certo sentido, o contraste é um requisito mínimo, e algumas combinações contrastantes são mais agradáveis aos olhos do que outras, as "cores de alto contraste, como uma mancha azul num fundo amarelo, chamam mais a atenção que emparelhamentos de baixo contraste, como uma mancha amarela num fundo laranja". ${ }^{7}$ A lei do contraste delineia e dirige a atenção para os limites entre os objetos; no contraste está o limite.

O contraste pode ser alto, médio ou baixo; o princípio é utilizado para imprimir o ritmo da obra, e por isso torna-se essencial saber o que nos revela o contraste. No carrossel (fig. 8) de Nikolai Sapunóv (1880-1912), as cores primárias contrastantes são utilizadas para delimitar o espaço de cada elemento composicional da obra. O contraste pode estar presente em uma obra límpida de ruídos (fig. 7), como a de Nikolai Rérikh (18741947), substancializando a obra ao clarear o céu com o branco-luz e demarcar as pessoas em tons laranja-amarelo-fogo; ou o contraste pode enriquecer uma obra de estilo completamente distinto e trazer consigo a aplicação de mais um princípio, o de solução de problemas (fig. 8).

Os princípios dialogam entre si, a cor pode ditar o padrão e o ritmo - pela via da consistência ou repetição de elementos de uma obra por se expressar nela o movimento, como ocorre no carrossel. $O$ ritmo traz atividade à obra. Ao mesmo tempo, o contraste precisa reforçar as diferenças e a diversidade da obra, fornecendo a ela a quebra das repetições. Na música é possível encontrar essa quebra para provocar o ouvinte; Bach é um excelente exemplo. A articulação ou movimento a direcionar o leitor fazem com que seus olhos permaneçam nela - composição fechada - ou transbordem seus limites - composição aberta.

7 Ibidem, p. 277-279. 
Ludmila Menezes Zwick
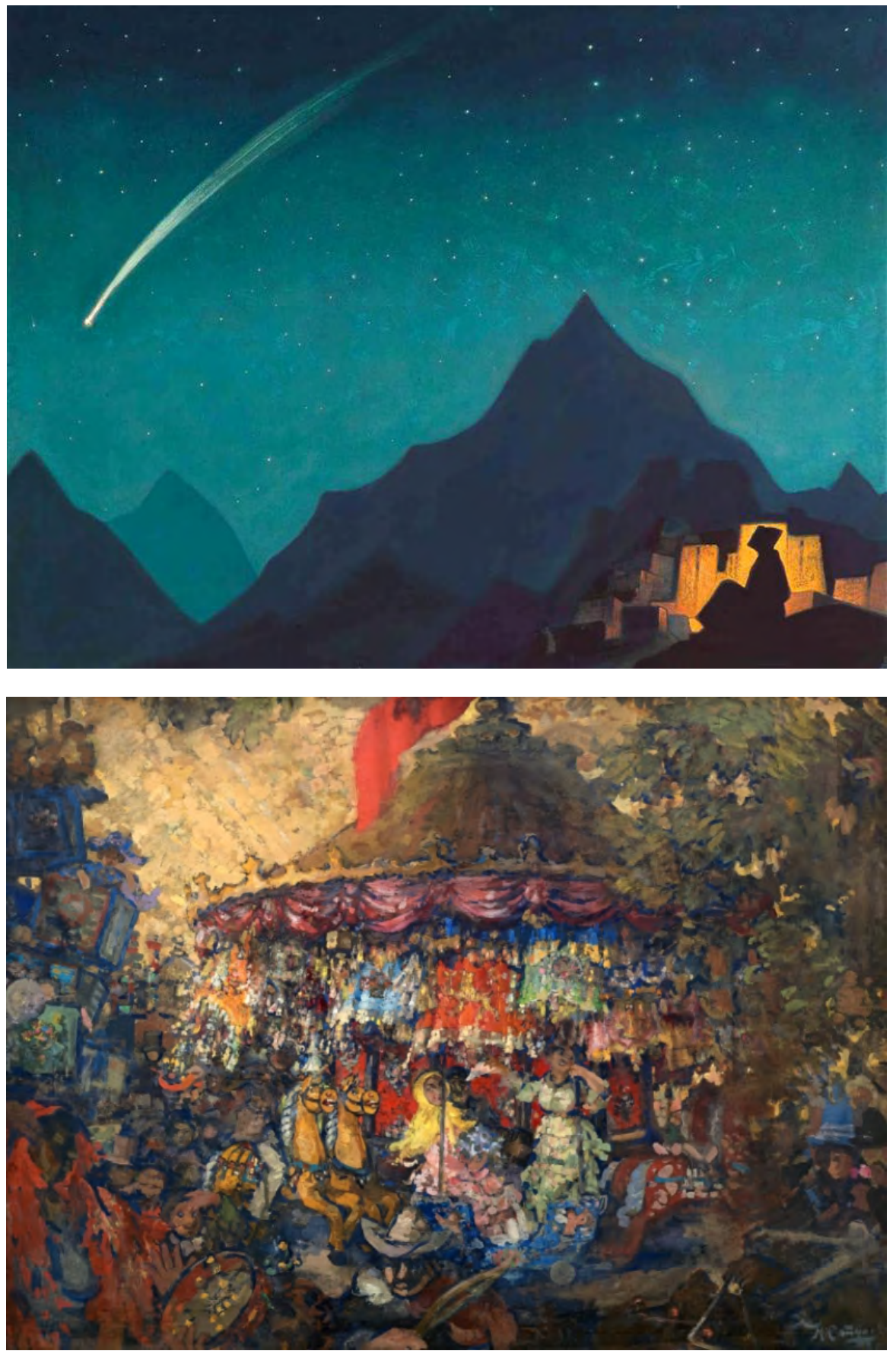

Fig. 7. Estrela do herói, Nikolai Rérikh, 1936, têmpera sobre tela, 92,3×122cm. Museu Nikolai Rérikh, Nova York.

Fig. 8. Carrossel, Nikolai Sapunóv, 1908, óleo sobre tela, $146,5 \times 196,5 \mathrm{~cm}$. Museu Estatal Russo, São Petersburgo. 
Fig. 9. Prece, Kazímir Malévitch, 1907, têmpera sobre madeira, 99x72,5cm. Museu Estatal Russo, São Petersburgo.

\section{A lei do isolamento}

Nesse princípio, o isolamento proposital de um único módulo visa a alocar a atenção do leitor da obra. Nele, "o artista enfatiza uma única fonte de informação - como cor, forma ou movimento - e subestima ou apaga deliberadamente as outras fontes"; enquanto o efeito de deslocamento de pico traz o exagero e a hipérbole à arte, o isolamento subestima-os. Ramachandran reitera a eficácia de um esboço para nós, pois as células no córtex visual primário - onde ocorre o primeiro estágio do processamento visual - se interessam por linhas, respondendo, assim, aos limites e bordas das coisas e sendo insensível às regiões despojadas de características da imagem. Com isso, ele ressalta que podemos prestar atenção "a um único aspecto da imagem ou a uma entidade de cada vez", e, ainda, que na dinâmica da percepção, "um percepto estável (imagem percebida) exclui outros de forma automática". Ao olharmos para uma imagem colorida, a nossa atenção distrai-se na confusão de textura e outros pormenores da composição, e, ao olharmos um mesmo objeto em esboço, os nossos recursos se voltam para saber onde está a ação. A lei do isolamento concorda com a modularidade - "diferentes estruturas cerebrais são especializadas em diferentes funções" -, o que explicaria a criatividade. ${ }^{8}$

Os princípios de deslocamento de pico, agrupamento e contraste, aparentemente, se mostram fáceis de detectar; mas a arte visa a ultrapassar o estri-

${ }^{8}$ Ibidem, p. 280-282. 
Ludmila Menezes Zwick

Fig. 10. Uma figura flutuante, Vassíli Kandínski, 1942, óleo sobre tela, $26 \times 20 \mathrm{~cm}$. Musée Zervos, Vézelay

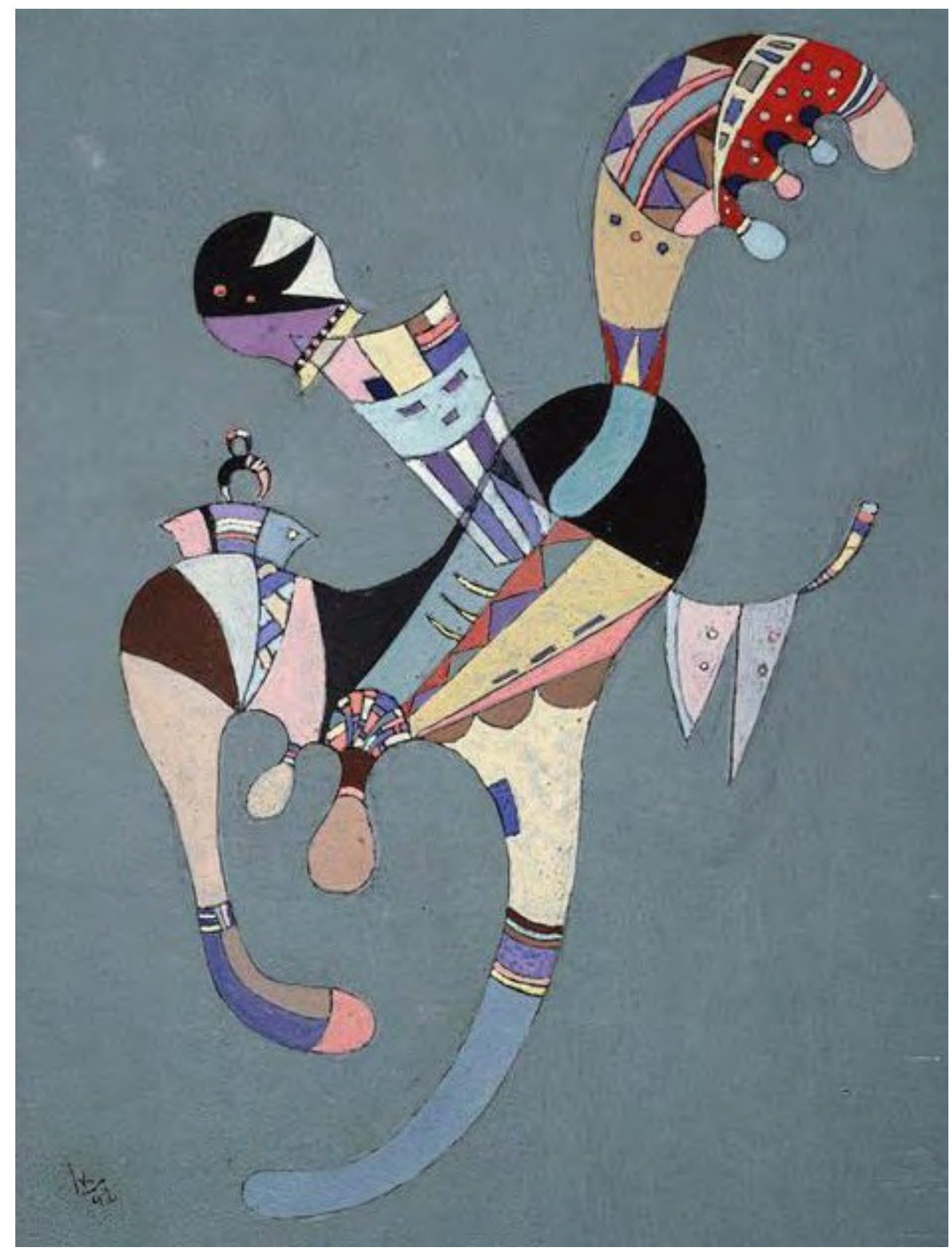


tamente representacional para expressar uma perspectiva específica, ou uma série de perspectivas, o que ampliaria os recursos derivados desses prismas, do que se encarregaria o deslocamento; já o direcionamento de nossa atenção visual se dá pelo exercício do agrupamento, do contraste e do isolamento, que, embora figure como contraintuitivo, delimita o raio de vislumbre da obra.

Ao isolar uma única modalidade visual, o artista intenciona amplificar o sinal dessa modalidade; Matisse expressou-se em algumas de suas obras utilizando esse princípio. $O$ direcionamento da atenção do leitor da pintura para uma única fonte faz-se para que este possa perceber os aprimoramentos do artista, seu apelo. A obra pode assentar-se nesse princípio, mas também utilizar-se de outros para que a experiência visual do leitor se torne mais agradável ou mais impactante. Ao aspirar a esse efeito, a produção de uma obra de arte demanda esforços por parte do artista em subtrair as trajetórias de movimento e amplificá-las, o que foi bem realizado por Malévitch e Kandínski na arte figurativa.

\section{A lei do esconde-esconde ou solução de problemas perceptuais}

A lei do isolamento assemelha-se superficialmente à do esconde-esconde, ou solução de problemas perceptuais, mas ela é bem distinta; "a arte envolve hiperativação de áreas visuais e emocionais", contudo, ainda preferimos o ocultamento, para que possamos decifrar enigmas; a percepção teria mais relação com essa decifração e "tanto delírios quanto percepções emergem do mesmo conjunto de processos. A diferença decisiva é que, quando estamos percebendo, a estabilidade dos objetos e eventos externos ajuda a ancorá-los"; já nos delírios, os objetos e eventos vagam em qualquer direção. Nesse caso, a arte atingiria seu clímax quando, após todos os preliminares visuais, reconhecemos o objeto. ${ }^{9}$

${ }^{9}$ bidem, p. 288-290. 
Preparamo-nos para derrotar os elementos escondidos numa imagem em que precisamos solucionar os problemas perceptuais para que, por meio de nossa visão, saibamos exatamente $o$ que $o$ artista quis nos dizer em imagens; tentamos descobrir o tom da obra, seu ruído, no caso de obras com fundos barulhentos, ou o som mais linear, no caso daquelas com fundos amenos. O significado da obra está implícito e não explícito. Podemos verificar esse efeito com mais clareza nas

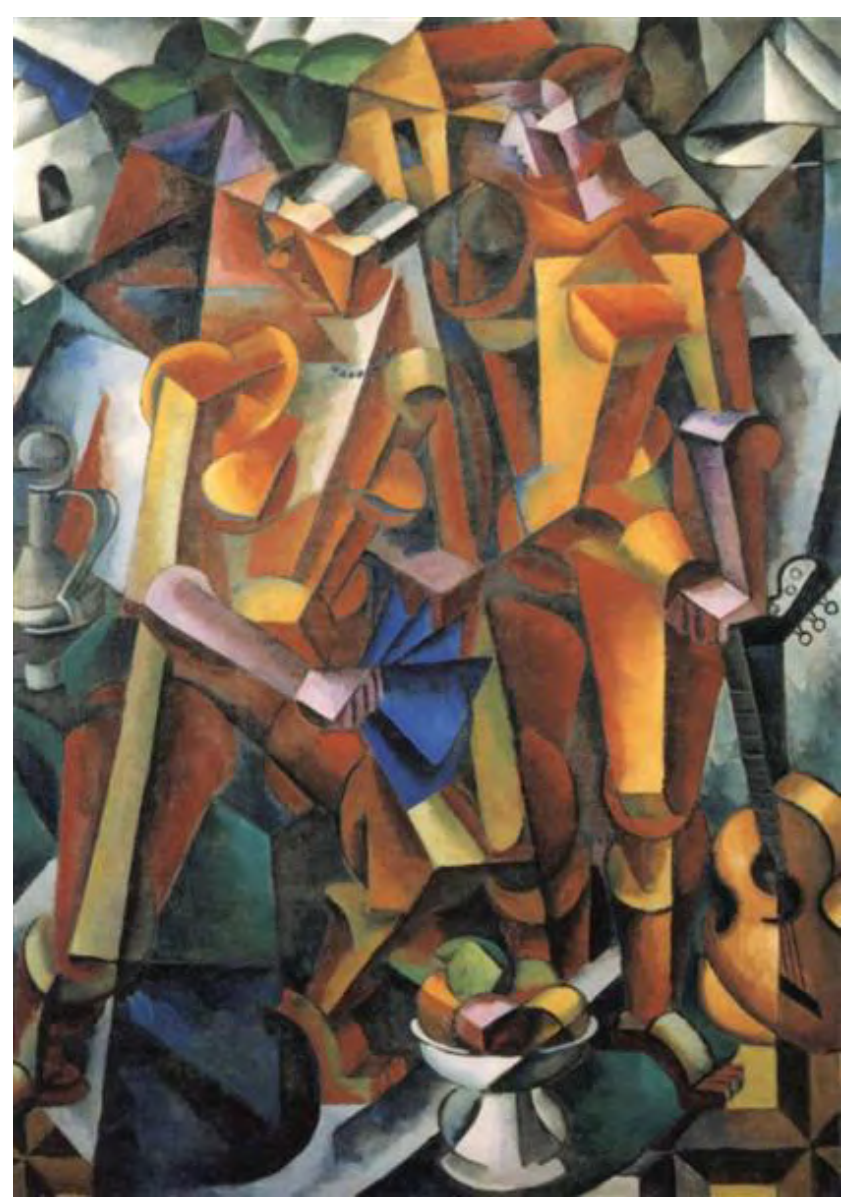
obras de artistas como Liubóv Popóva (18891924), ou ainda de Nadiéjda Udaltsóva (18861961), Juan Gris (1887-1927) e Georges Braque (1882-1963), nas quais temos que buscar o sentido e, por vezes, completar as figuras mentalmente. Contudo, em alguns artistas esse efeito aparece em tom mais fluído e numa linguagem mais tênue, como em algumas obras de Mikhail Vrúbel (1856-1910), ou ainda no não amontoamento das formas, mas sim das cores, nas obras do já citado Konstantín Koróvin e de Nikolai Féchin (1881-1955). Popóva realizou uma série de obras nesse sentido, em seu retorno a Moscou no verão de 1913, por meio da fusão do cubismo francês com a vanguarda russa.

A solução de problemas perceptuais, além de permitir a sobrevivência do homem, relaciona-se também ao que Arnheim entende por cognição, como aquisição de conhecimento no sentido mais amplo, ou seja, a interação e não a dissociação de duas habilidades, a da intuição e a do intelecto, tanto do leitor/

Fig. 11. Composição com figuras, Liubóv Popóva, 1913, óleo sobre tela, $160 \times 124,3 \mathrm{~cm}$, Galeria Tretiakóv. espectador de uma obra de arte quanto do artista. Como resultado de uma dessas interações, podemos citar a descoberta da fórmula geométrica para a perspectiva central feita no século $\mathrm{XV}$; ao prescrever um ponto de fuga comum, essa descoberta apenas teria codificado a solução para um problema que já 
As leis da estética na arte russa

havia sido inteiramente pesquisado pela intuição, ${ }^{10}$ estamos prontos para intuir e deduzir

${ }^{10}$ ARNHEIM, 1997, p.205.

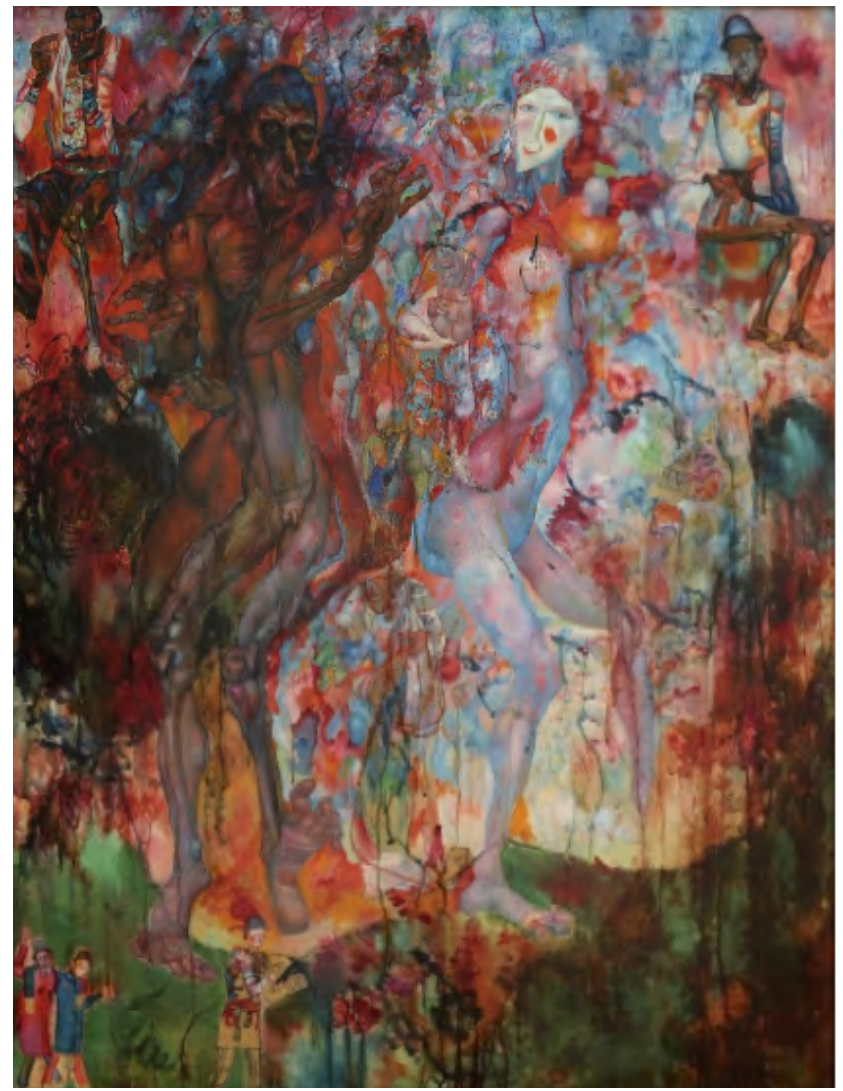

Fig. 12. Homem e mulher, Pável Filónov, 1912-1913, óleo sobre tela, $155 \times 121 \mathrm{~cm}$, Museu Estatal Russo.

Fig. 13. Paris. Bulevar dos Capuchinhos, Konstantín Koróvin, 1911, óleo sobre tela, 65,2 x 81,2cm. Galeria Tretiakóv, Moscou.

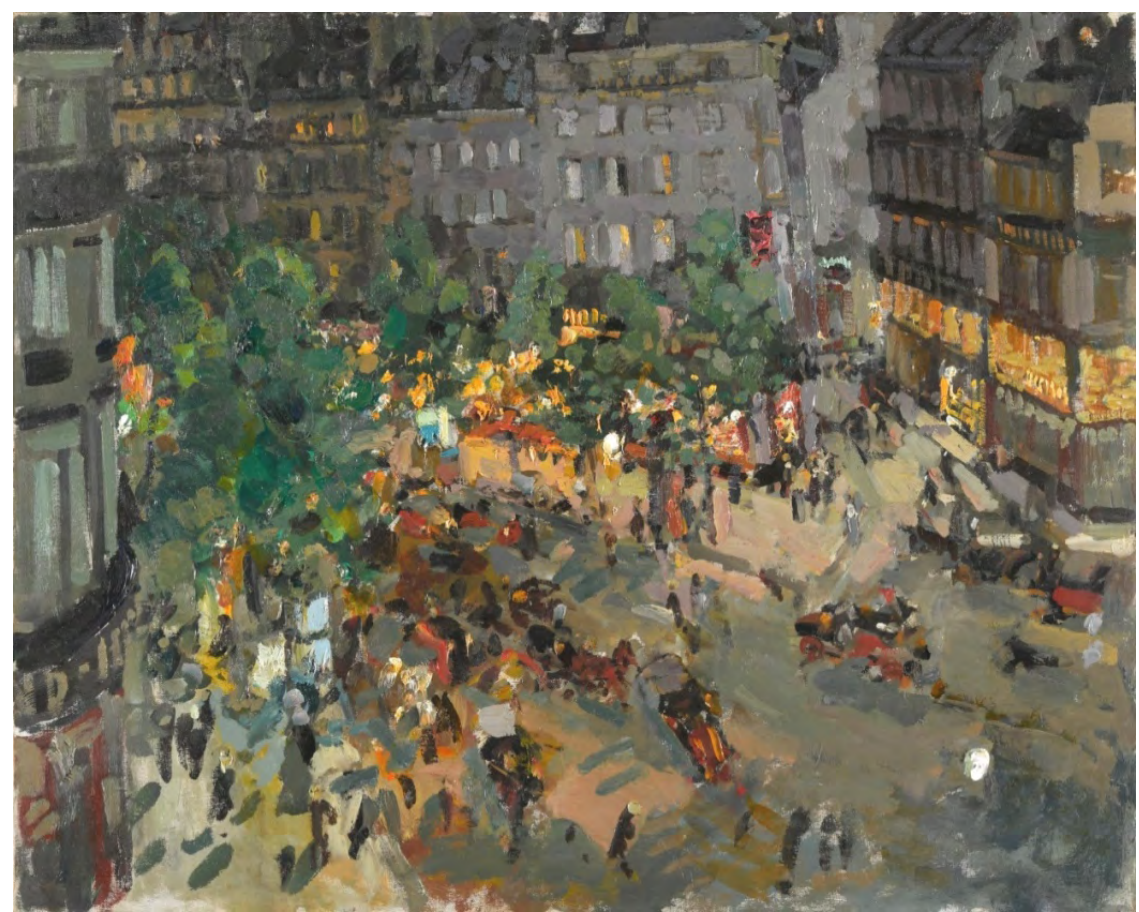




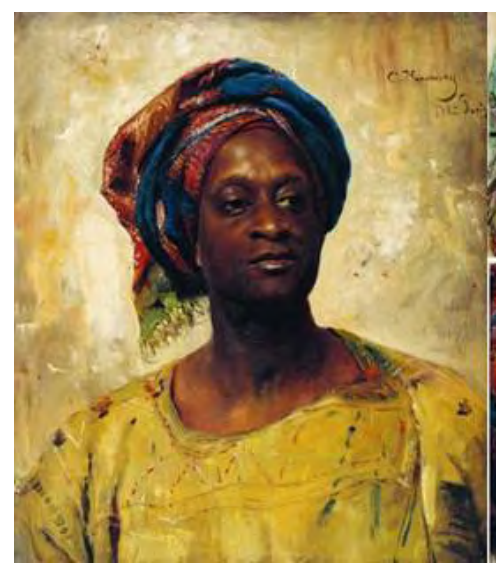

Fig. 14. Árabe com turbante, Konstantín Makóvski, 1882, $64,5 \times 54 \mathrm{~cm}$, e rostos assimétricos forçados à simetria, da obra de Konstantín Makóvski.

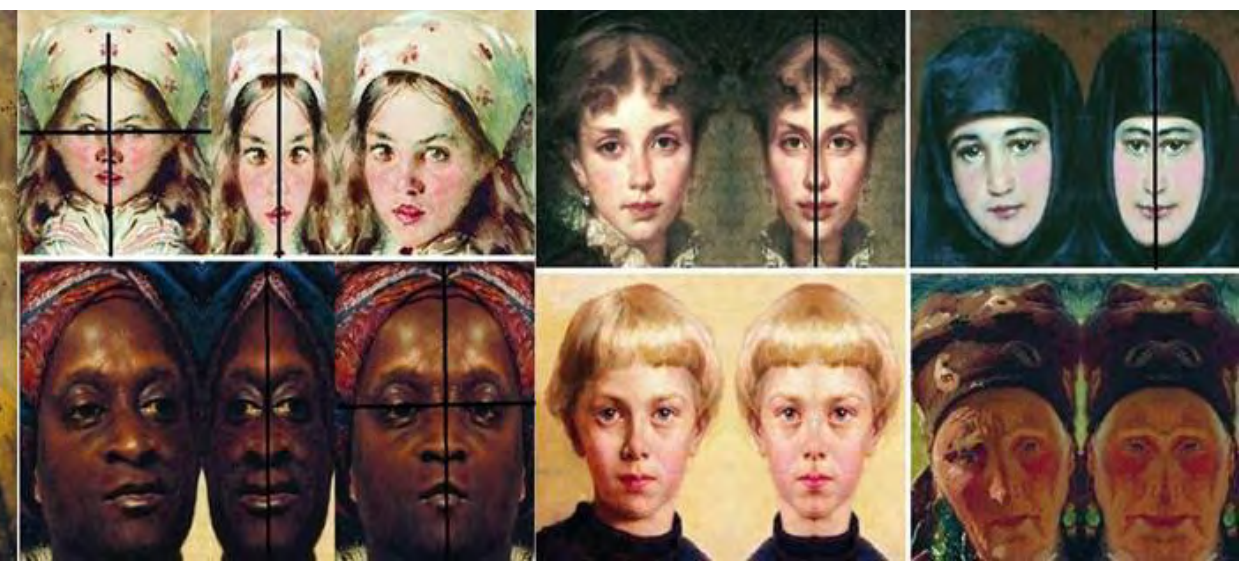

que as formas geométricas ou as pinceladas aparentemente dispersas reúnem-se para formar um homem, um elemento ou vários.

\section{A lei da simetria}

Nessa lei, temos a sedução de que a simetria, para Ramachandran,11 poderia ser explicada segundo duas ideias. A primeira é a de que a visão se desenvolveu "principalmente para descobrir objetos" e nossos campos visuais estão sempre repletos deles: "árvores, troncos caídos, manchas de cor no chão, riachos céleres, nuvens, afloramentos de rochas e assim por diante". Por ter uma limitada capacidade de atenção, nosso cérebro desenvolveu um mecanismo para alocar a atenção, a criação de uma hierarquia que na natureza traduz "objetos biológicos" como "importante", e esses objetos, voltados à satisfação, têm algo em comum com a simetria; "um bebê recém-nascido prefere olhar para manchas de tinta simétricas a olhar para as assimétricas", expressando assim uma regra do cérebro. A segunda força evolucionária volta-se para a simetria nos rostos que são considerados mais atraentes; uma "infestação parasítica pode reduzir enormemente a fertilidade e a fecundidade de um parceiro potencial, por isso a evolução atribui elevado valor à capacidade de detectar se o parceiro

11 RAMACHANDRAN, Op. cit., p. 296-298. 

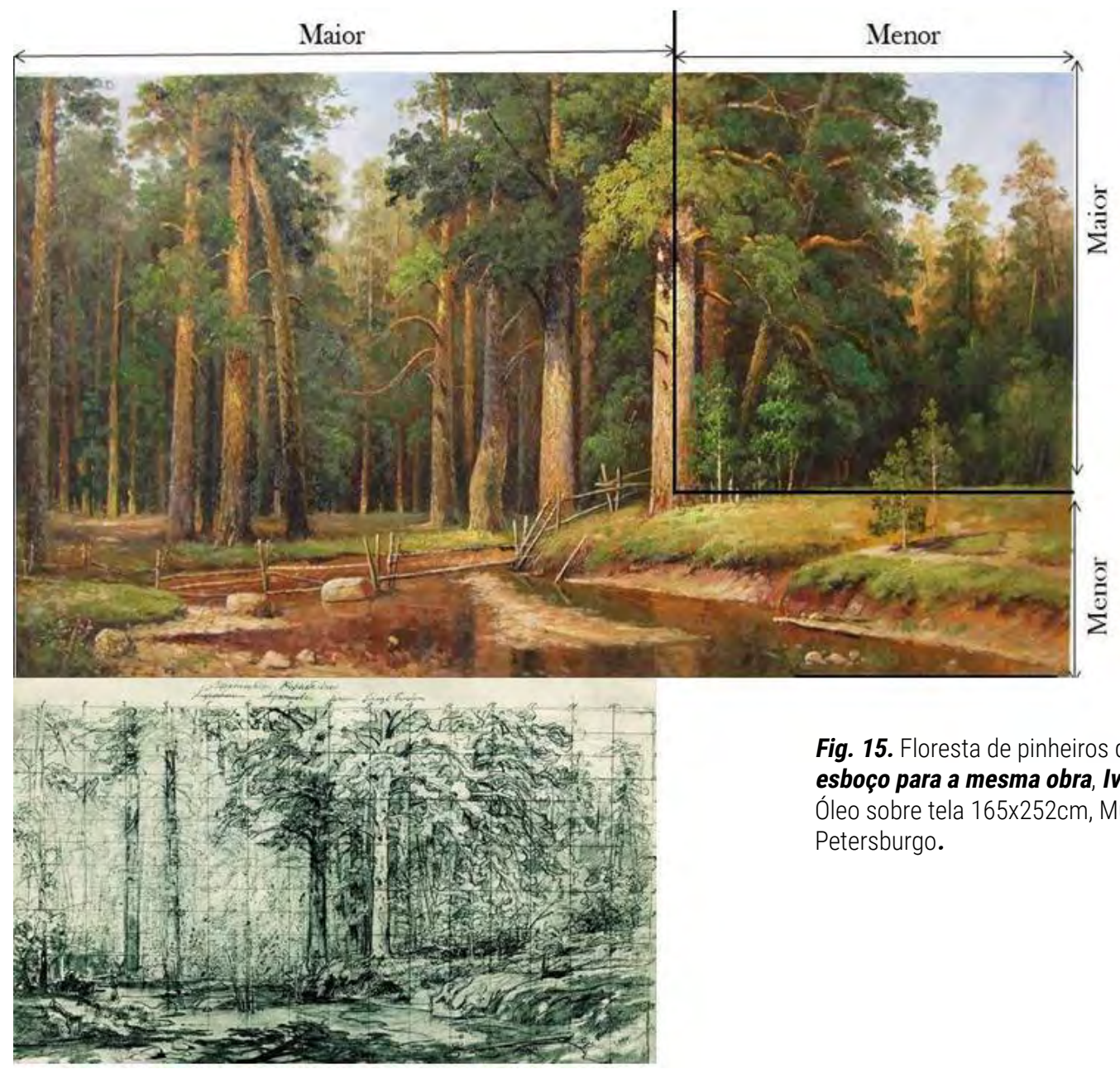

Fig. 15. Floresta de pinheiros quais mastros de navio $\boldsymbol{e}$ esboço para a mesma obra, Ivan Chíchkin, 1898.

Óleo sobre tela 165×252cm, Museu Estatal Russo, São Petersburgo.

está infectado"; a simetria passa a ser um marcador inconsciente de boa saúde, algo desejável que nos deixa diante de um paradoxo, pois a simetria se aplica a objetos e não a cenas de grande escala; nos últimos casos, preferimos a assimetria. Preferimos objetos simétricos e cenas assimétricas, pois "os objetos dispostos de maneira simétrica numa sala pareceriam algo absolutamente tolo, porque, como vimos, o cérebro não gosta de coincidências que não pode explicar".

Contudo, nem sempre a simetria dita à estrutura rigorosos requisitos de perfeição matemática, que convergem em uma pequena lista de possíveis realizações, e depois se vale dessa lista como manual de construção para o nosso modelo de mundo; a simetria converteu-se em uma ideia blasfemante por 
sua audácia, ao afirmar que pode decodificar os métodos de trabalho do artesão, inclusive sugerindo precisamente como fazê-lo. ${ }^{12}$ Um artesão criador de um mundo físico a partir do mundo das ideias é um bom artista; ele seria um copista "cujas criações refletem a confusão dos materiais disponíveis", que pode desfocar os pormenores num mundo físico que é uma representação imperfeita da realidade última que devemos procurar. ${ }^{13}$

A assimetria é utilizada nos figurinos de teatro, juntamente com o recurso do movimento; o movimento auxilia na desregulamentação da mensagem artística. Inclusive quando a arte é assimétrica, ela tem, em sua lógica, o princípio do que é simétrico. Em sua pequenez assimétrica, a menina que traz, em sua singeleza, as flores mais acessíveis a qualquer coletor, fala-nos da beleza como experiência, a beleza como a construção de uma explicação das coisas simples. A representação vem na contramão de artistas que evitaram representar essas formas disformes, pertencentes à natureza das pessoas e da própria natureza. A mensagem da imprecisão das formas humanas.

A simetria ${ }^{14}$ ou a assimetria no rosto foi objeto de estudos fotográficos mais recentes, e tem-se claramente a noção de que um rosto perfeitamente simétrico não se torna necessariamente mais atrativo ou belo; por exemplo, se nos retratos seguintes Konstantín Makóvski optasse pela simetria, o efeito seria no mínimo estranho, e não um estranhamento atrativo, mas um estranhamento repulsivo. A assimetria traz belas disparidades nas faces humanas e, certamente, os artistas possuem senso disso.

\footnotetext{
12 WILCZEK, 2015, p. 45.

13 Ibidem, p. 56.

${ }^{14}$ No caso desses rostos, trata-se da simetria axial, que é distinta da simetria radial; neles, os elementos iguais do retrato são equidistantes a partir da linha reta, denominada axial, mas também são opostos. Nesse caso, ao invés de proporcionar a ordem e a harmonia conferidas pela simetria, os rostos tornaram-se estranhos; quando assimétricos esses rostos tornam-se mais agradáveis aos olhos. A assimetria exacerbada tem certa relação com o deslocamento de pico e demonstra que a beleza é uma grande variável.
} 
A simetria é um princípio aparentado à disposição metódica e ao equilíbrio; trata-se da difícil aspiração de expressar a unidade na diversidade, um árduo ensejo da arte, pois reconhece que a reprodução na tela de qualquer objeto visível advém da observação minuciosa da complexidade e da interconexão, da apreensão da harmonia na natureza e sua posterior expressão pela via de uma análise ponderada gradual. Assim, esse princípio ordena as sensações para harmonizar as várias relações e deslocá-las à sua maneira, criando algo inspirado na natureza, de acordo com uma lógica nova e original, o que comumente se vê em artistas como Chíchkin. ${ }^{15}$

\section{A lei da aversão a coincidências}

Essa lei, assim como a da simetria, do ordenamento e do equilíbrio, quase sempre tem relação com o não burlar de outras normas, por exemplo, da perspectiva e do ponto de fuga, que quase sempre são burladas em leis como a do agrupamento, o que é comum no cubismo, que inverte o ponto de fuga ou, no mínimo, o elimina ao evitar deixar evidente o caminho do olhar do observador. Propositalmente, coloca-se o observador da obra de uma perspectiva de um, dois ou três pontos de fuga, para que ele seja capaz de repudiar a coincidência de um determinado elemento do quadro, ou seja, ele é deixado diante de algo descentralizado propositalmente e se vale de uma tendência de nosso cérebro, que "sempre tenta encontrar uma in-

\footnotetext{
15 Outro exemplo de simetria nos é dado pelo último trabalho de Chíchkin, de 1898, e mencionado por Stakhov (2009, p. 53-54), no qual a imagem da floresta de pinheiros "é considerada um ponto culminante digno de sua carreira original e criativa. A imagem tem uma forma clássica perfeita, do ponto de vista da integridade e da composição". Ela faz parte das criações baseadas nas florestas da sua terra natal, "onde encontrou sua própria síntese idealista de harmonia e grandeza" (Ibidem.). Nela, o artista exemplifica um conhecimento profundo da natureza russa, que foi acumulada por ele ao longo de seus quase cinquenta anos de vida criativa. Para ele, é evidente que a lei da seção áurea pode ser encontrada na imagem bem conhecida; o pinheiro no plano horizontal (visto em primeiro plano) e iluminado brilhantemente pelo sol divide a pintura pela seção áurea nessa direção. À direita do pinheiro, o outeirinho iluminado pelo sol divide o plano vertical da imagem na seção áurea. A partir da esquerda do primeiro plano de pinheiros, podemos ver muitos outros pinheiros. A divisão da parte esquerda do plano horizontal da imagem em si sugere o uso da mesma seção. E, ainda, a presença das linhas verticais e horizontais brilhantes, que dividem a imagem na seção áurea, produz o equilíbrio e a calma consonantes à intencionalidade do artista.
} 
terpretação genérica alternativa, para evitar a coincidência", e que também "luta para encontrar uma explicação para a coincidência e se frustra porque não há nenhuma". ${ }^{16}$ De um modo aparentemente aleatório, o leitor da obra encontra-se contemplado em suas suspeitas, por deparar-se com elementos que estão precisamente em pontos vazios do espaço, "coisas" colocadas no espaço solto, como a Lua de Aivazóvski e Levitán.

A narrativa pictórica de Aivazóvski calcula matematicamente os elementos composicionais, para que nenhum deles ocupe o centro da obra; nenhuma das embarcações, nenhuma das construções arquitetônicas, nem a capela, nem a mulher, sequer a lua ou as nuvens atrapalham a passagem da luz refletida na água oscilante. $O$ contraste é menos intenso para dar vazão à reflexão em meio à quietude, diferentemente das muitas obras de batalhas navais em que o artista reforça o contraste para acentuar o caráter belicoso. 0 mesmo recurso de dar ênfase à lei da aversão às coincidências é utilizado em

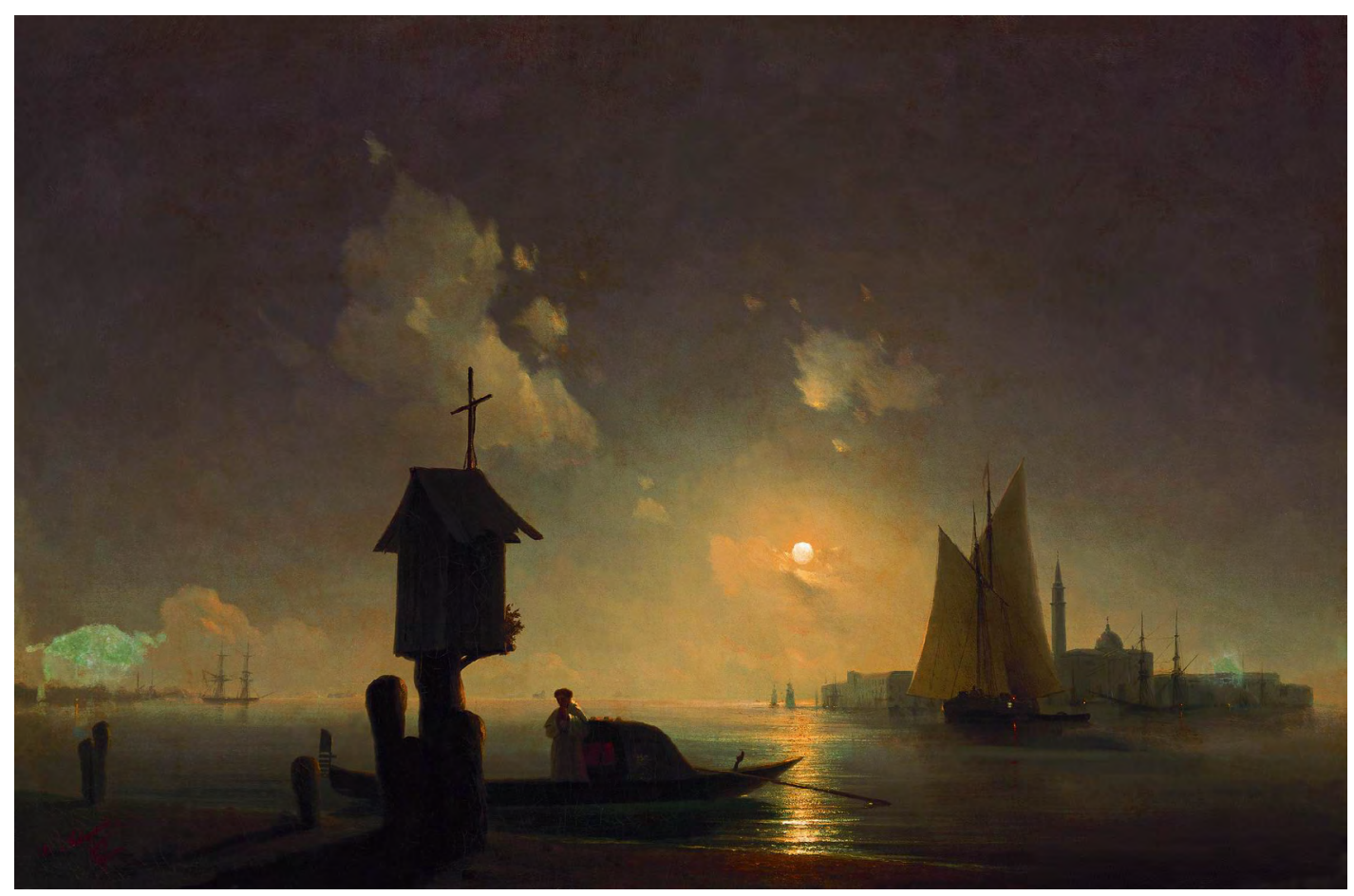

Fig. 16. Vista marítima com capela na margem, Ivan Aivazóvski, 1845, óleo sobre tela, $58 \times 88 \mathrm{~cm}$. Museu de Arte de Odessa.

${ }^{16}$ RAMACHANDRAN, Op. cit., p. 293-294. 
Fig. 17. Crepúsculo. Lua, Isaák Levitán, 1899, óleo sobre tela, $49,5 \times 61,3 \mathrm{~cm}$. Museu Estatal Russo, São Petersburgo.

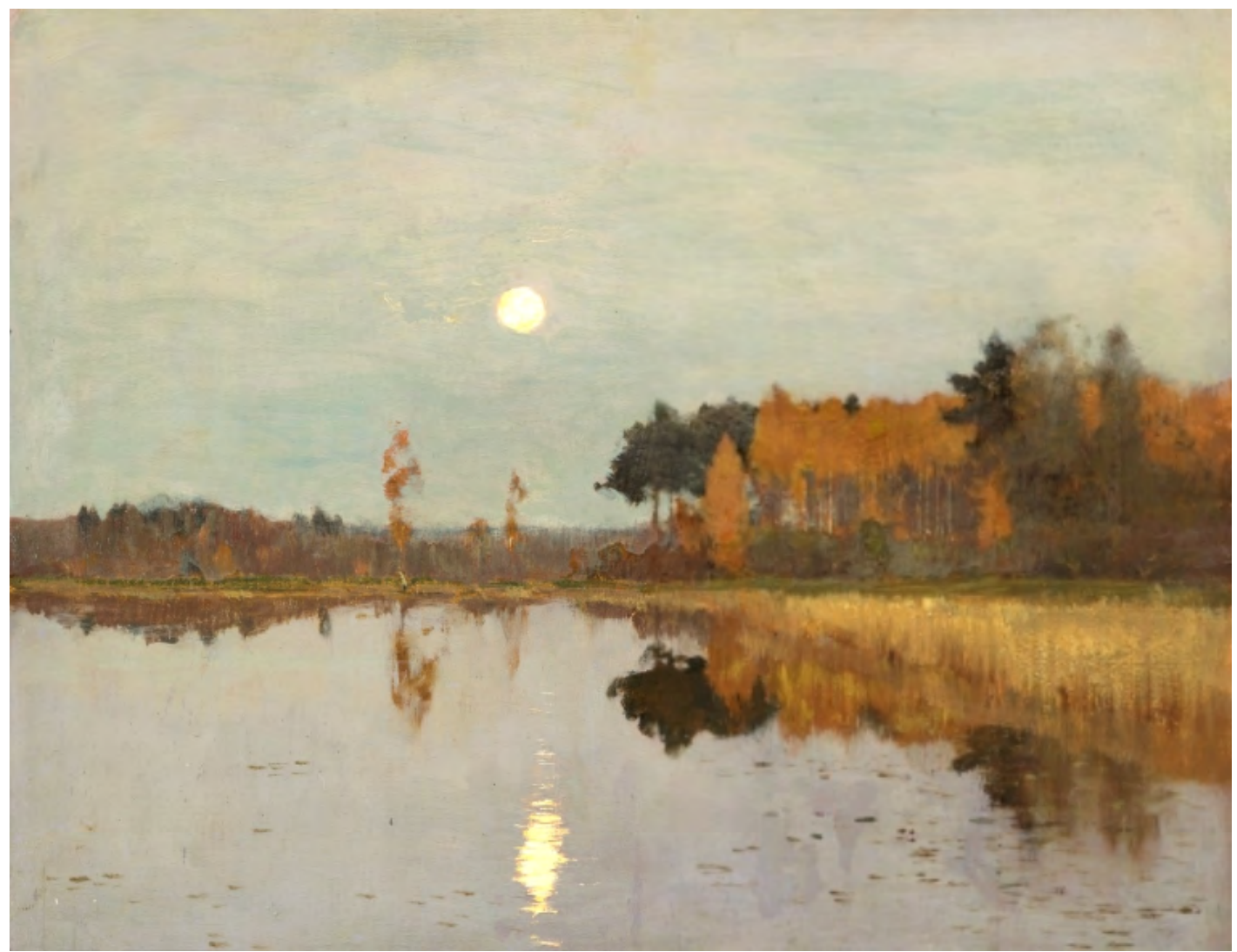

obras com a reunião de menos elementos. Nossos olhos seguem a curva cintilante da água até a Lua. No caso de Levitán, nosso olhar busca a Lua solta no céu, bem como o reflexo da Lua solto na água.

A arte tenta fazer com que o real, inteiramente racional, possa aplacar toda a sede do emocional. Na irreprimível vontade de viver ao encontro da morte, a expressão faz-se como uma superação da vida; a obra de arte embrenha-se na imagem do que a vida deveria ser; a atividade artística - que tem na realidade sua fonte - supõe, é verdade, uma espécie de recusa do real, mas tal distancia-se de ser uma simples fuga ou refúgio do nostálgico curso inevitável do rio da vida, pois passa por mergulhares mais profundos. $O$ artista, então, recria o mundo por sua conta. A arte é o universo em que a ação encontra a 


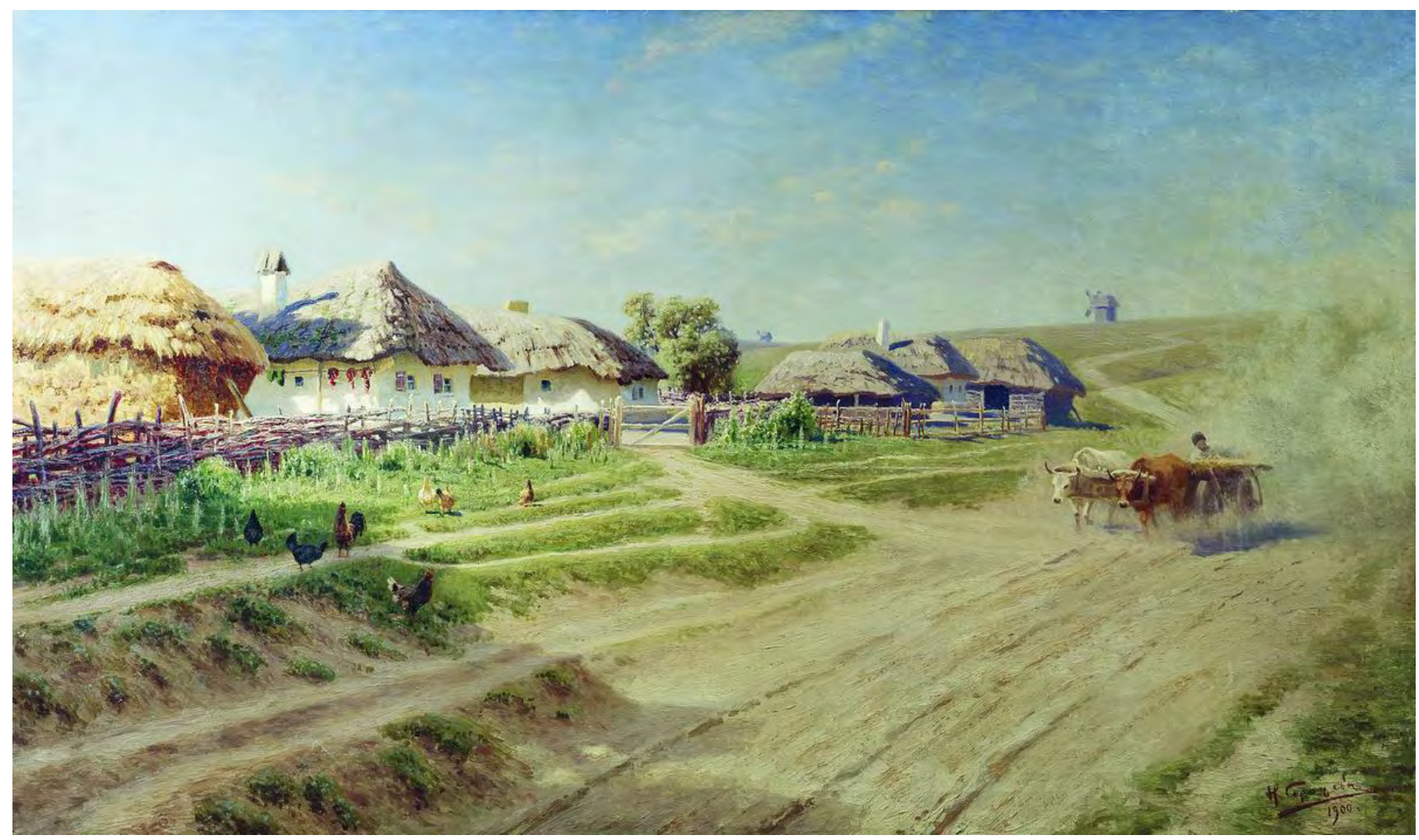

Fig. 18. Rua de vilarejo ucraniano, 1900, Nikolai Sérguiev, óleo sobre tela, $117 \times 197 \mathrm{~cm}$. Museu de Arte, Tcherepovéts, Região de Vólogda. forma, como nem sempre acontece na vida; ela consuma aspirações, ela dá forma ao desespero sem forma da vida. Em meio aos elementos da pintura: composição, movimento e ritmo, proporção e unidade, podemos encontrar orladuras muito bem planejadas, nada aleatórias, regidas por alguns princípios conhecidos pelo artista; o crepúsculo de Levitán suprimiu qualquer coincidência, do mesmo modo que aderiu também à metáfora.

\section{A lei da repetição, do ritmo e da ordem}

O ritmo faz-se com elementos recorrentes, elementos que podem ser similares, criando um ritmo irregular, ou idênticos, criando um ritmo regular. Podem ainda, pela harmonia da imagem, realizar-se em uma repetição lógica, ou pela dissonância desta, em uma repetição ilógica, ou simplesmente uma padronização que evite uma variação muito intensa a fim de enfatizar algum ponto da obra. 
O princípio da disposição metódica, ou ordenamento, que remete à regularidade, tem relação com o ritmo e denomina-se "ordem". Nele, Ramachandran ${ }^{17}$ reúne vários princípios que em comum possuem "uma aversão ao desvio em relação a expectativas (por exemplo, a preferência por bordas retilíneas e paralelas e pelo uso de motivos repetitivos em tapetes)". Como é improvável que a "realidade" seja sempre regular ou previsível, a arte busca essa regularidade; "a necessidade de regularidade ou ordem pode refletir uma necessidade mais profunda que nosso sistema visual tem de economia de processamento". Tal lei compromete-se com a criação de efeitos agradáveis.

O ordenamento dita o ritmo do carro de bois a talhar a estrada de terra seca e levantar poeira, de modo que essa narrativa de um único instante de um vilarejo forma-se diante de nosso olhar revelando o ciscar das galinhas à beira, a porteira, os paióis, as modestas moradias, o condutor do carro e, especialmente, a reunião desses elementos num todo.

Nessa lei, as obras funcionam segundo o princípio da navalha de Ockham, um princípio lógico que explica qualquer fenômeno, assumindo as formas das premissas estritamente necessárias à explicação de sua mensagem; o artista eliminou todos os excessos para não causar nenhuma diferença aparente nas predições da hipótese ou teoria de sua própria narrativa. Trata-se do princípio da parcimônia, numa narrativa que não insere nada além de sua necessidade enunciativa, com poucas premissas simplificadoras da visão do leitor, que não precisa derrotar camuflagens, pois nenhuma personagem ou elemento essencial à obra encontra-se dissimulado. A obra é uma narrativa com uma explicação singela; também é o caso do ordenamento entre o branco da neve e o marrom dos tron$\cos$ (fig. 19 e 20).

${ }^{17}$ Ibidem, p. 294. 
Ludmila Menezes Zwick

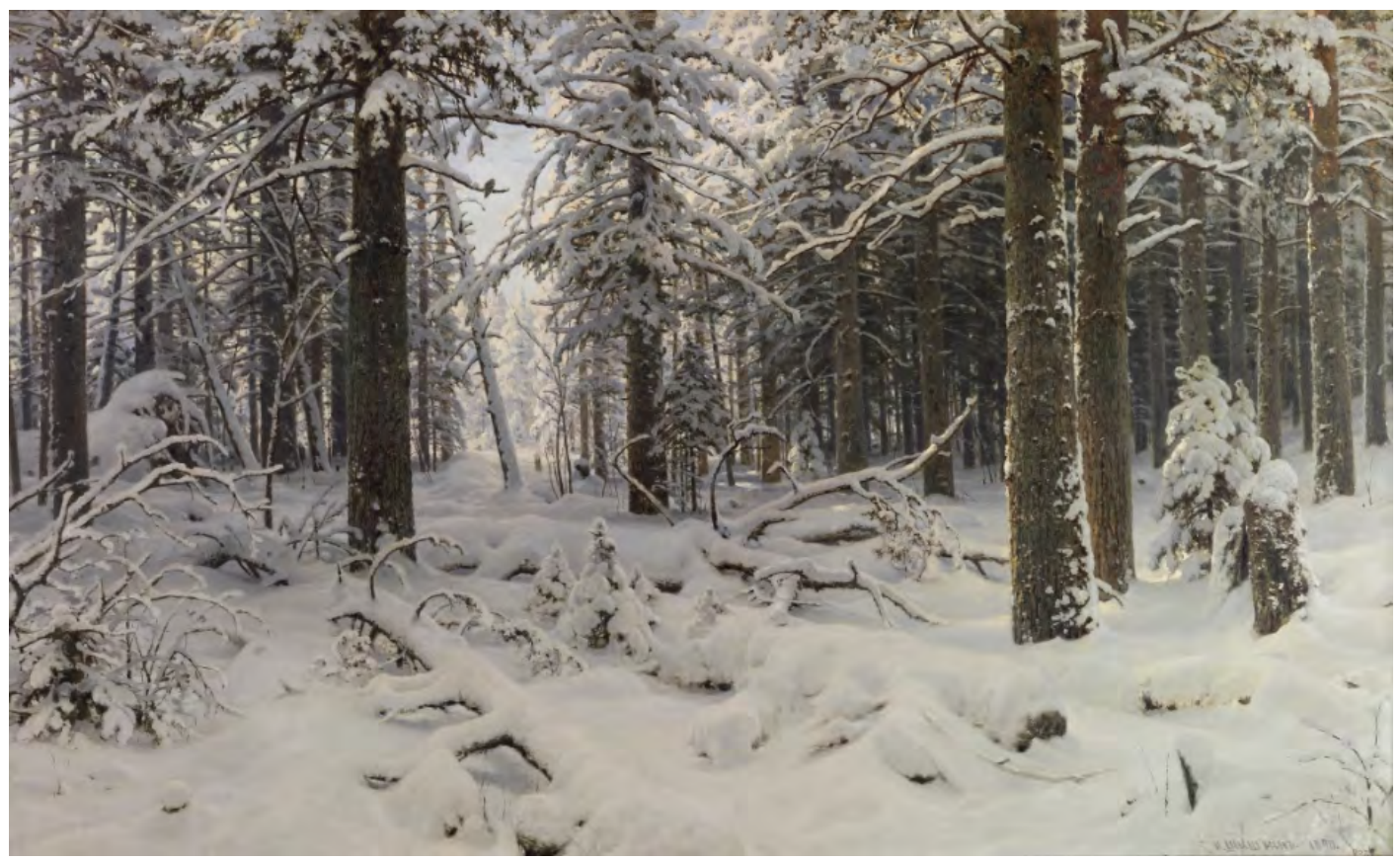

Fig. 19. Inverno,

Ivan Chíchkin, óleo sobre tela, 1890,

$125,5 \times 204 \mathrm{~cm}$. Museu Estatal Russo, São Petersburgo.

Fig. 20. Estrada invernal, Aleksiéi Savrássov, 1870 óleo sobre tela, 47,5x71cm. Museu Nacional de Arte da República da Bielorrússia.

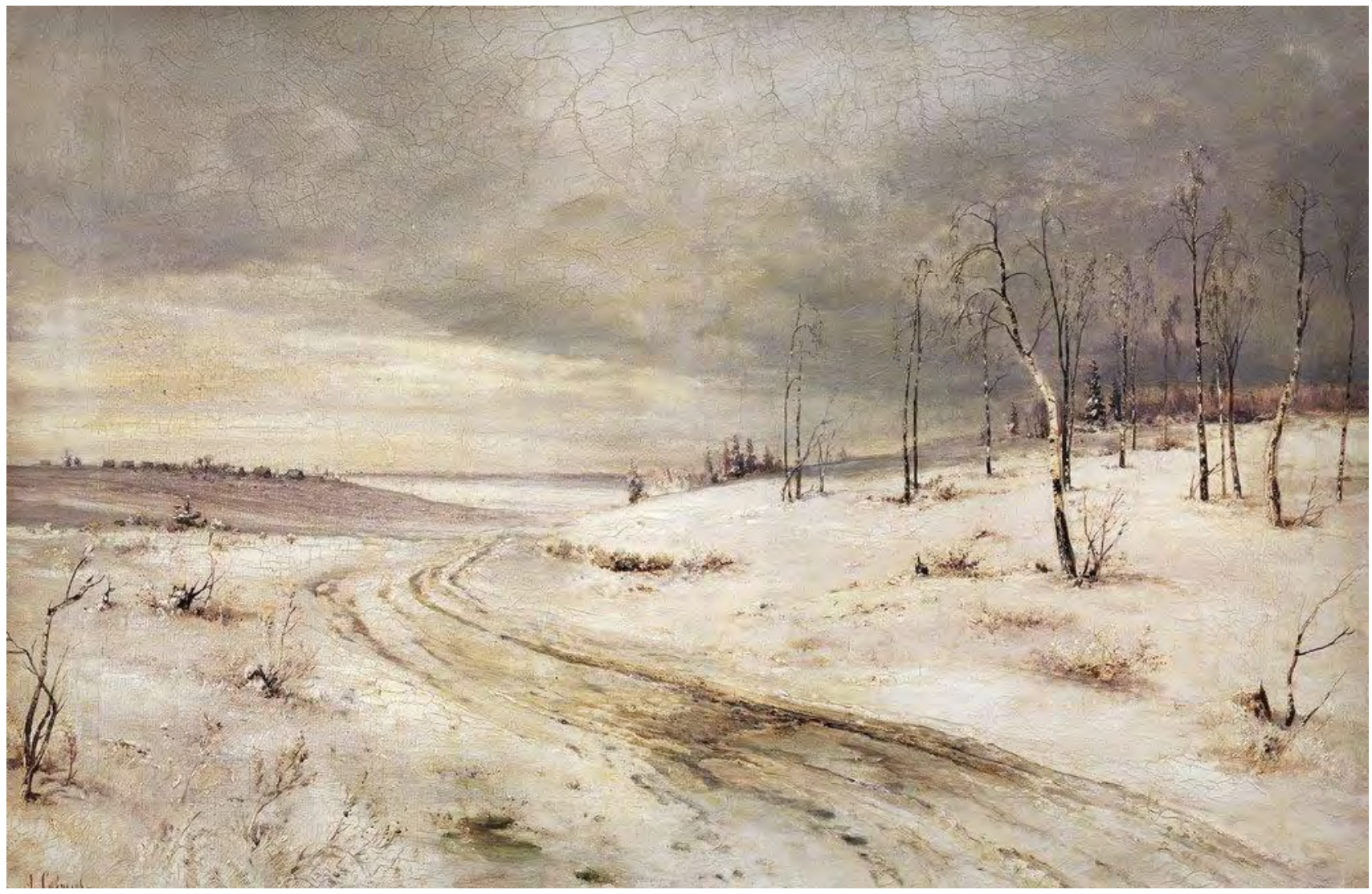




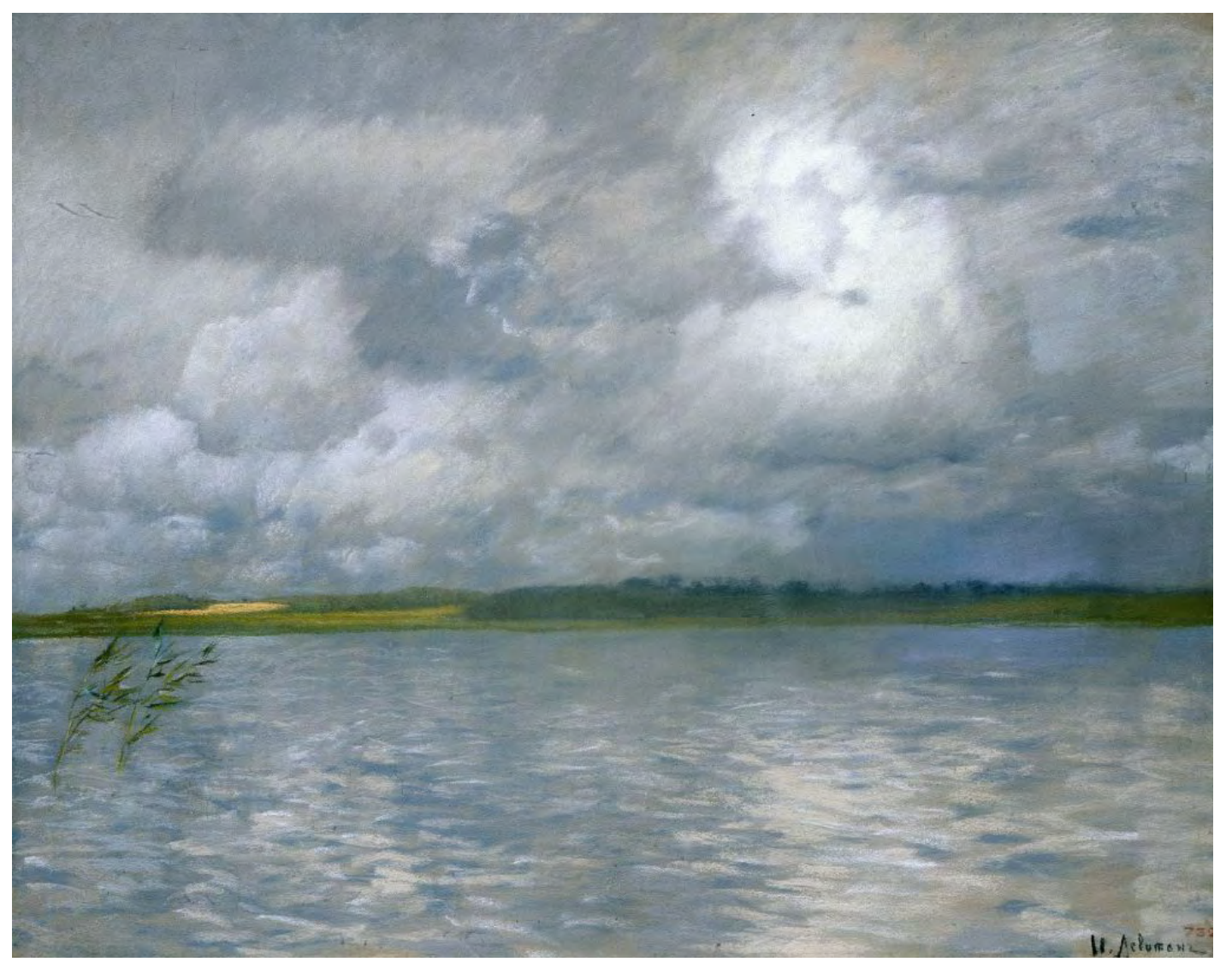

Fig. 21. Dia

encoberto, Isaák

Levitán, 1895,

óleo sobre tela,

$48 \times 62 \mathrm{~cm}$. Museu

Estatal Russo, São

Petersburgo.

\section{A lei do equilíbrio}

O equilíbrio ${ }^{18}$ faz com que todos os elementos de um trabalho se harmonizem de forma que nenhuma parte da obra se sobreponha ou pareça mais pesada que qualquer outra. Artistas como Chíchkin, Savrássov, Aivazóvski e Levitán (fig. 15 a 17,19 a 24) convocam-nos ao senso harmônico, incluso o balanço da cor. Essa configuração melodiosa pode ter relação com a metáfora, uma vez que, para Ramachandran e Hirstein, além de um dispositivo de comunicação eficaz, esta seria um mecanismo cognitivo básico para codificar um universo numa forma condensada que o signifique. A nós parece que essa lei

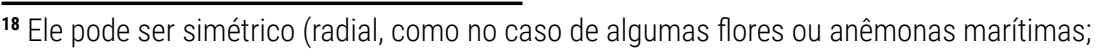
uma variação da simetria radial, em que partes iguais se arranjam em torno de um eixo central, como no pentamerismo; ou ainda bilateral, a chamada simetria de plano, como numa folha de laranjeira, em que suas metades direita e esquerda se espelham) ou assimétrico.
} 
Fig. 22. A criação do mundo, Ivan Aivazóvski, 1864, óleo sobre tela, $195 \times 236 \mathrm{~cm}$. Museu Estatal Russo, São Petersburgo. se relaciona em primeira instância à lei do princípio da disposição metódica; pois a estabilidade da obra depende do contrabalancear entre o muito que ela quer evocar e um pequeno espaço em que cabe uma única imagem - o que é um recurso da poesia. Para tal, essa obra almeja uma resposta emocional, sem que se necessite explicitar o que ela metaforiza. Foge, assim, do recurso retórico para alcançar o recurso poético em algumas pinturas. No caso das obras voltadas à sensualidade, essa reação explicita-se mais, contudo, em obras com questões muito profundas, esse princípio da arte que se baseia em princípios cognitivos fundamentais precisa ser acionado com maior intensidade.

Para dar estabilidade à obra, o artista vale-se de todos os recursos metafóricos e não metafóricos pelos quais trilhou 
sua existência; revisita em si próprio as imagens e suas experiências, tal como o cerne de seu apelo afetivo para emitir sua mensagem. Para harmonizar da forma mais sublime, a imagem precisa ter uma mensagem poderosamente forte, ainda que o grito de sua voz seja o silêncio; Levitán foi um Shakespeare no enunciado de uma mensagem preponderante ao colocar em curto espaço uma imagem que comporta a vida. De modo similar, artistas como Savrássov e Aivazóvski aportam num único condensado os muitos significados e os sentidos a eles associados, provocando uma forte experiência estética ao atingirem, com a pintura, a poesia, que se tornou uma entidade à parte, ao invés de apenas significá-la.

Esse tipo de obra diz a cada um o que cada um quer ouvir; cada verso pictórico encontra seu leitor. "A arte, em suma, talvez seja a realidade virtual da própria natureza."19 Uma razão menos prosaica para a atratividade da arte e sua atemporalidade talvez seja que ela fala uma linguagem onírica, "baseada no hemisfério direito, que é ininteligível - estrangeira, até para o mais literal hemisfério esquerdo. A arte transmite matizes de significado e sutilezas de humor que só podem ser vagamente apreendidas ou transmitidas pela linguagem falada"; ${ }^{20}$ os dois hemisférios podem utilizar códigos neurais diferentes para representar funções cognitivas superiores, e a arte talvez seja a facilitadora da comunhão entre esses modos de pensamento, que permaneceriam separados um do outro por um muro. É possível que as emoções também necessitem de "ensaio na realidade virtual para aumentar sua gama e sutileza para uso futuro". ${ }^{21}$ À medida que o cérebro evoluiu, ele passou da fase de representação para a de metarrepresentação - representações de representações, uma ordem elevada de abstração -, a qual se relaciona com os nossos valores, crenças e prioridades, como também com o nosso senso de individualidade e de atribuição de significado no mundo externo.

Na tela, o homem dá a si próprio a forma e o limite apaziguador que busca na vida, cria em caótica harmonia o seu mundo,

\footnotetext{
${ }^{19}$ RAMACHANDRAN, Op. cit., p. 306-307.

20 Idem.

21 Ibidem, p. 308-311.
} 
Fig. 23. Silêncio, Isaák Levitán, 1884, óleo sobre tela, $96 \times 128 \mathrm{~cm}$. Museu Estatal Russo, São Petersburgo. como Aivazóvski (fig. 22). 0 artista tenta, em sua individualidade, estudar o mundo e refazê-lo com o que lhe falta, o pintor isola seu tema para unificá-lo, o paisagista isola no espaço e no tempo o que muda com a luz e perde-se numa perspectiva ou deixa de existir sob o impacto do fugidio, algo frequente em Levitán (fig. 21; 23); o artista elimina e elege simultaneamente para nos dar a ideia de que a imagem foi feita ainda há pouco e que seus elementos ou suas personagens continuam vivos pelo milagre da expressão; a imagem precisa superar a realidade.

\section{A lei da metáfora}

"Quem faz metáforas, falando literalmente, mente - e todo mundo sabe disso". ${ }^{22}$ Nas imagens, as metáforas são utilizadas visando fins escondidos, mas, ao mesmo tempo, explícitos, inclusive nas propagandas. As metáforas são "amplamente utilizadas nas artes visuais" ${ }^{23}$ As ninfas ou outras figuras femininas, por exemplo, aparecem como metáforas "da fertilidade e da fecundidade na natureza". ${ }^{24} \mathrm{Em}$ algumas obras, existem várias camadas metafóricas e significativas, "quase como se

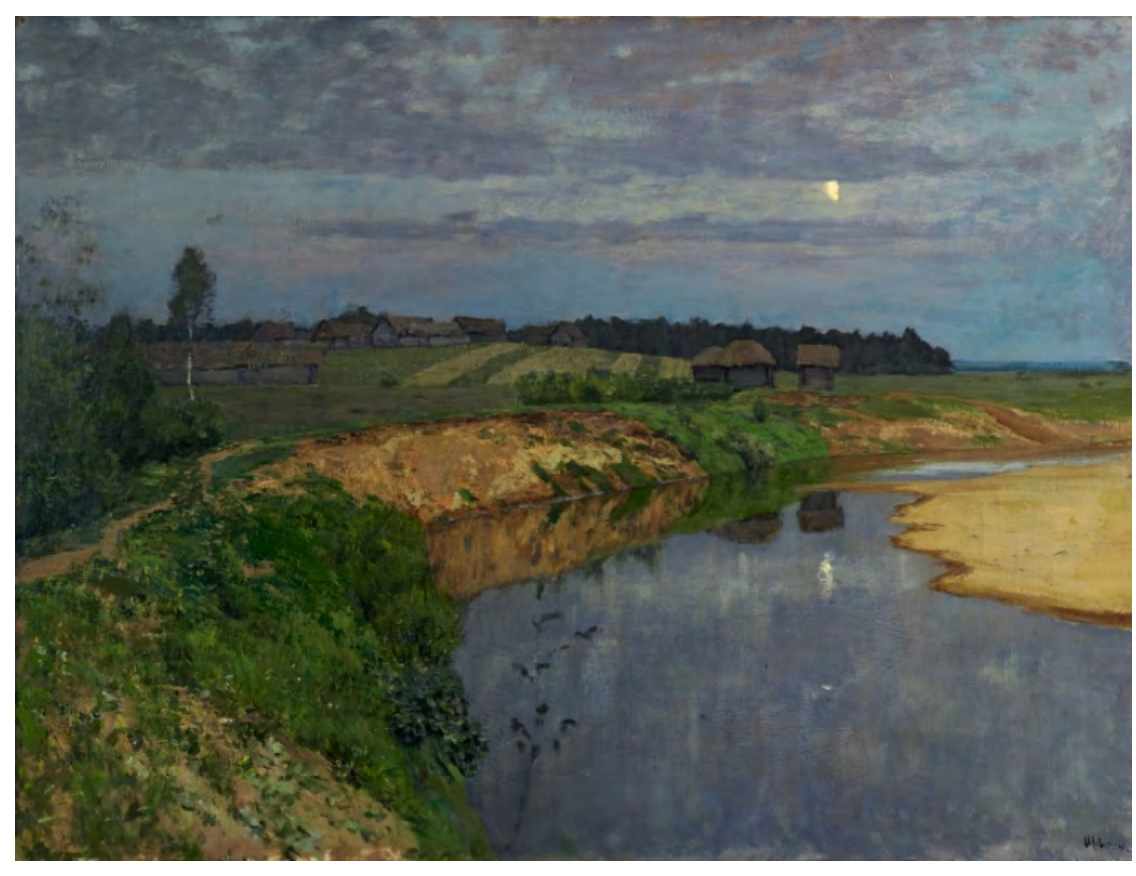
múltiplas metáforas se ampliassem umas às outras, embora não se saiba por que essa ressonância e harmonia interna devam ser especialmente agradáveis". ${ }^{25} \mathrm{O}$ artista cria a partir da existência de uma realidade objetiva humana e expressa-a com o intuito de demarcar seu posicionamento no universo. Trata-se de uma busca por

\footnotetext{
22 ECO, 1984, p. 144.

${ }^{23}$ RAMACHANDRAN, Op. cit., p. 298-299.

24 Idem.

25 Idem.
} 


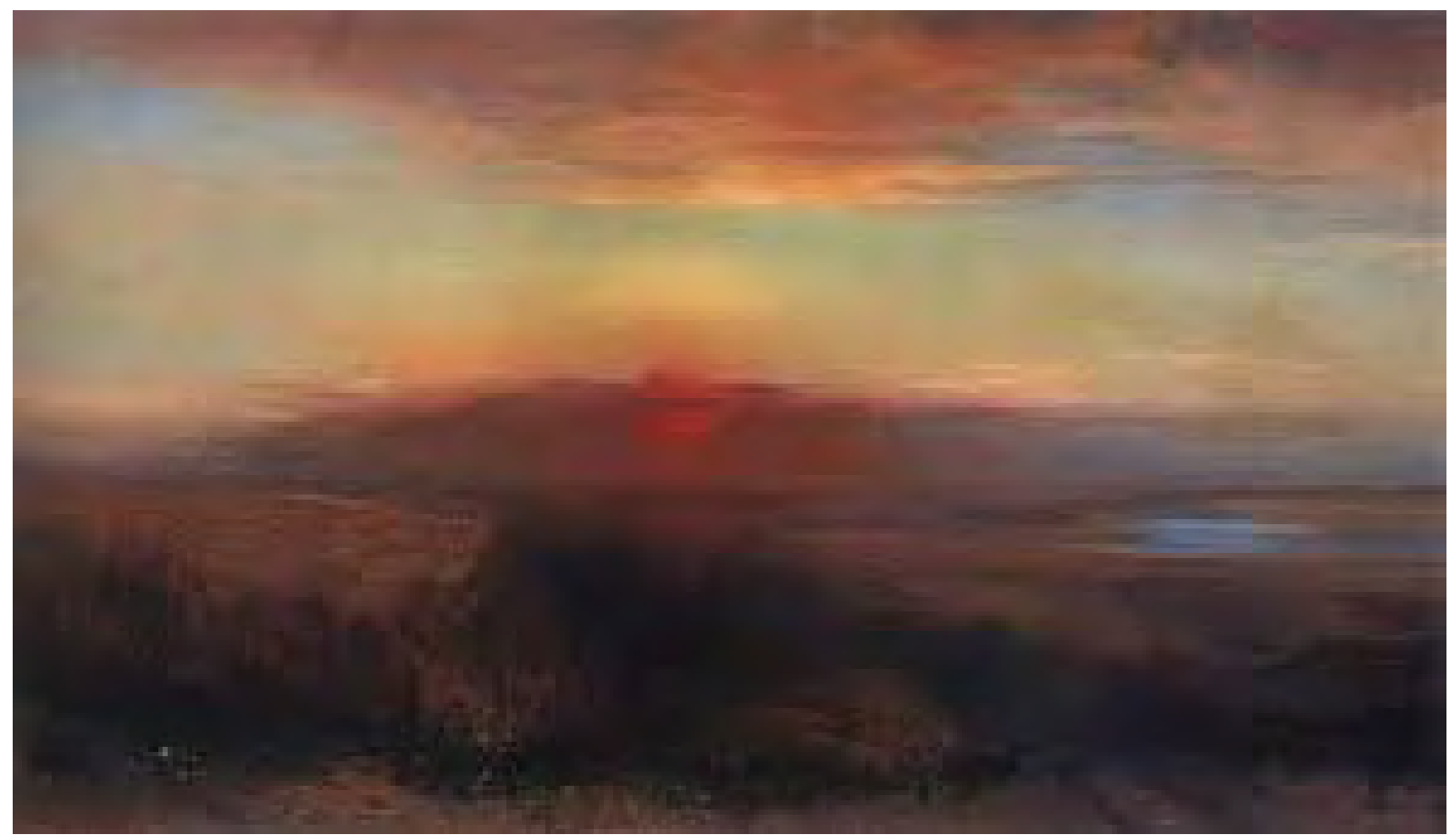

Fig. 24. Centeio, Aleksiéi Savrássov, 1881, óleo sobre tela, $67 \times 117 \mathrm{~cm}$. Museu Regional de Belas Artes de Rostóv, Rostóv do Don. um diálogo harmônico ou caótico entre a realidade, a percepção desta na construção do pensamento e o estado emocional. De certo modo, cada narrativa de um único instante espelha a exata efemeridade de seu tempo e reverbera para outros tempos o que está na mente do artista. O objeto artístico pronto, a pintura, resulta de uma percepção da ideia visual pela via pictórica de um determinado artista; a imagem concretiza sua percepção. O processo criativo da arte não possui divisórias absolutas. Onde a metáfora é mais forte, a poesia pictórica também o é; a calmaria do bucólico-metafórico (figs. 17 e 23) de Levitán, bem como o vento dando rumo ao reflexo do céu na água (fig. 21), a força visceral do mar e o ar fabuloso (fig. 22) de Aivazóvski reúnem condições humanas muito variadas em um único enredo.

Essa personalização evoca, por vezes, a capacidade tanto do artista quanto do leitor de estabelecer vínculos arbitrários entre entidades perceptuais aparentemente não relacionadas; tal capacidade sinestésica seria a chave para a elaboração das 

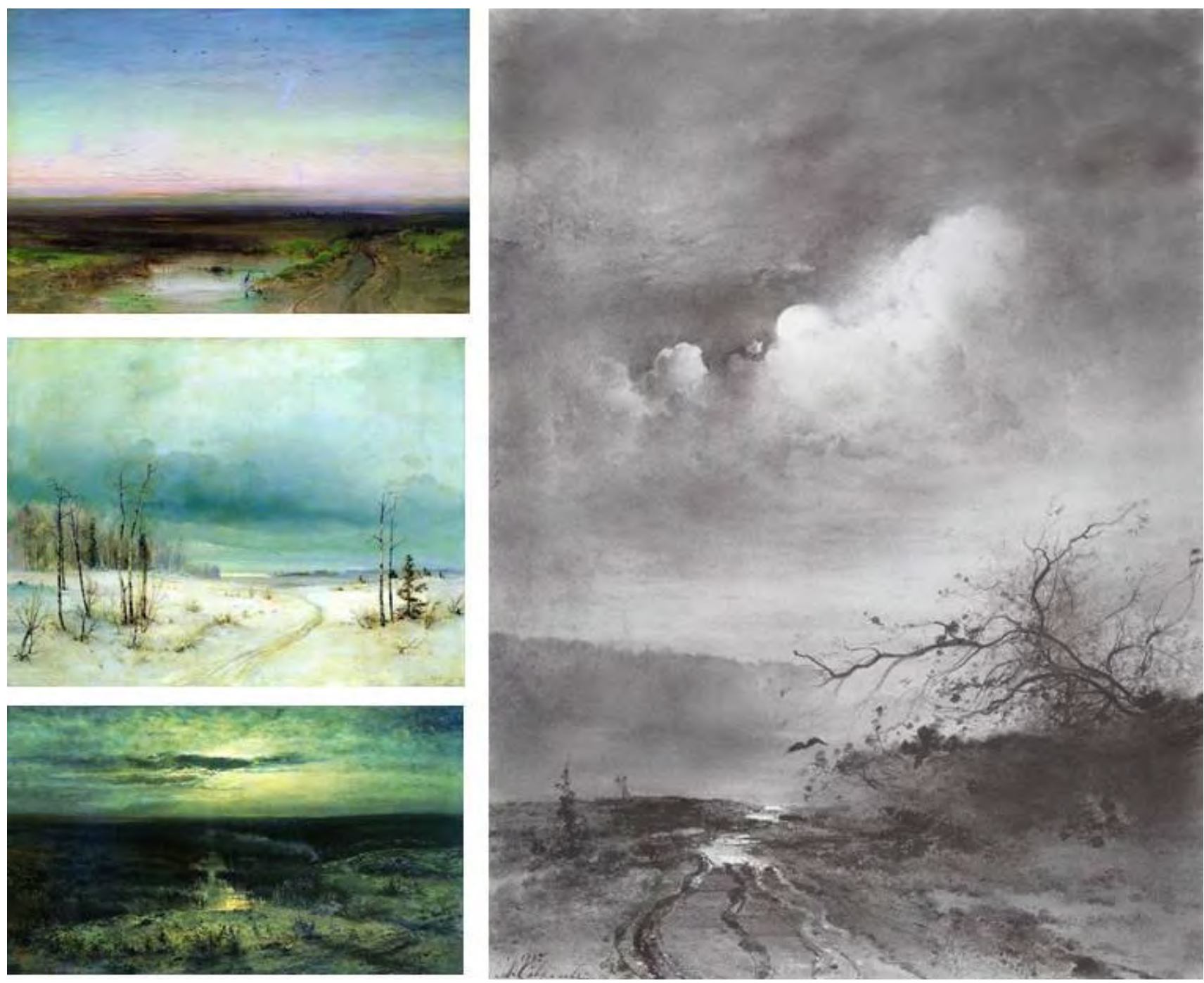

Fig. 25. Poente, Aleksiéi Savrássov, 1870, óleo sobre tela, 29x44cm. Museu de Arte de Taganróg, Taganróg.

Inverno, Aleksiéi Savrássov, 1880, óleo sobre tela, $53 \times 71 \mathrm{~cm}$. Museu Estatal Russo, São Petersburgo.

Noite enluarada. Charco, Aleksiéi Savrássov, 1870, $46 \times 80 \mathrm{~cm}$. Museu de História da Arte, Sérpukhov.

Noite enluarada sobre rio, Aleksiéi Savrássov, 1885, óleo sobre tela, 37x27cm. Museu de Arte Regional de Tula, Tula 
metáforas. Quanto maior a capacidade de multiplicar bem os sentidos para uma única unidade pictórica expressiva, tanto mais Arte detém a narrativa pictórica. Portanto, a sinestesia transcende a metáfora e, por isso, pode explicá-la e trazer luz à compreensão da associação entre a cor e a emoção, viés da expressão de muitos artistas; como um fenômeno sensorial causado pela aparência visual real e não pelo conceito, a cor é experienciada por uma tonalidade emocional para os sinestesistas. Fato é que existe uma grande incidência de sinestesia em pessoas criativas. A nossa capacidade de revelar analogias ocultas é a base, segundo Ramachandran, de todo o pensamento criativo. As metáforas talvez permitam a efetuação de uma espécie de realidade virtual no cérebro. Para o estudioso, metáfora e sinestesia não são sinônimas, mas compartilham uma profunda conexão.

\section{Breve consideração final}

A expressão do artista afirma-se pelo tratamento que ele impõe à realidade. Se a recusa à realidade for intensa, o artista subtrai-a de sua obra; se não, ele a acalenta e a apresenta como tal, dentro das possibilidades de representação. Contudo, as leis estéticas reafirmam-se na arte, pois se relacionam ao cérebro - fonte da criação, observação e apreensão -; a recusa absoluta à realidade é impossível, do mesmo modo que uma produção cuja base seja o imaginário puro; a realidade precede a imaginação.

Ao aplicar princípios, o artista, para criar algo novo, precisa conhecê-los, mas também precisa realizar o que o poeta faz, dizer muito com poucas palavras, de modo que, ao reunir poucos elementos, comuns e inerentes à lógica do cenário escolhido para ser representado, ele provoca e apreende o olhar por conseguir dizer muito nesse pequeno espaço da tela. Confirmadores dessa faina são artistas como Savrássov, Levitán e Aivazóvski, capazes de compor com pouco, muito conteúdo; mestres na elaboração de uma poesia pictórica que reúne a natureza externa para confrontar a natureza interna ao homem. Ou ainda, artistas como Filónov, que, pela via da arte 
analítica, visa a sobrepor e concentrar condições humanas em meio à sociedade para conduzir seu leitor a uma reflexão cujo esteio não seja a quietude, mas o estardalhar concentrado das gentes, o que Levitán e Savrássov evitam.

Na sequência poética em cores mais frias (fig. 25), ou na obra erigida em cores quentes, por meio do solar triunfo sobre 0 campo de centeio (fig. 24), Savrássov elabora uma imagem que unifica as muitas possibilidades de imagens que poderiam emitir a mesma mensagem, ordena os elementos e os princípios para criar um sentimento de completude. Quantas imagens, assim como palavras, serviriam para descrever ou definir um pôr do sol, a chegada da noite, um inverno, um rio coberto pela névoa ou um campo de centeio. $O$ artista, cônscio dos princípios que pretende aplicar na tela, concretiza em tintas e formas os elementos a serem representados partindo daquilo que seu olhar selecionou da realidade, para que, nesse pequenino espaço, faça caber a grandeza de uma poesia pictórica, a qual, embora se baseie nas nuances da natureza, visa a atingir também as nuances da humanidade, que, embora desabite grande parte das obras desse artista, representada está na forma mais elevada da metáfora, aquela atrelada à existência. Trata-se de uma metáfora menos evidente do que aquela utilizada para sensualizar uma obra, por exemplo, e, ao mesmo tempo, trata-se de uma disposição metódica capaz de questionar o leitor em sua angústia ou conciliação mais profunda mediante a harmonização de uma mensagem que atingiu o porte de uma poesia pictórica.

\section{Referências bibliográficas}

ARNHEIM, Rudolf. Art and Visual Perception: A Psychology of the Creative Eye. Berkeley, Los Angeles, London: University of California Press, 1997.

ECO, Umberto. Semiotica e filosofia del linguaggio. Einaudi: Torino, 1984.

Ramachandran, V.S.; Hirstein, W. The Science of Art: a Neuro- 
logical Theory of Aesthetic Experience. Journal of Consciousness Studies, Exeter, v. 6, n. 6-7, p. 15-51, 1999.

The Artful Brain. In: Reith Lectures 2003: The Emerging Mind. Disponível em: http://www.bbc.co.uk/radio4/ reith2003/lecture3.shtml>. Acesso em: 24/02/2014.

The Neurological Basis of Artistic Universals. Disponível em: <https://notes. utk.edu/Bio/greenberg.nsf/0/7222777efe4b2d2885256e2c007d85f8>. Acesso em: 24/02/2014.

O que o cérebro tem para contar. desvendando os mistérios da natureza humana. Rio de Janeiro: Zahar, 2014.

; Hirstein, William. The Science of Art: A Neurological Theory of Aesthetic Experience. Journal of Consciousness Studies, v. 6, n. 6-7, 1999, p. 15-51.

STAKHOV, Alexey. The Mathematics of Harmony. From Euclid to Contemporary Mathematics and Computer Science. Singapore: World Scientific, 2009. (Series on Knots and Everything, 22)

WILCZEK, Frank. A Beautiful Question: Finding Nature's Deep Design. New York: Penguin, 2015.

ZEKI, Semir. Inner Vision: An Exploration of Art and the Brain. Oxford: Oxford University Press, 1999.

Splendours and Miseries of the Brain. Philosophical Transactions of the Royal Society B. London, v. 354, n. 1392, p. 2053-2065, Dec. 1999. 